\title{
PKR deficiency alters E. coli-induced sickness behaviors but does not exacerbate neuroimmune responses or bacterial load
}

\author{
David Chun-Hei Poon ${ }^{1}$, Yuen-Shan Ho ${ }^{4}$, Ran You' ${ }^{1}$, Hei-Long Tse ${ }^{1}$, Kin Chiu ${ }^{5}$ \\ and Raymond Chuen-Chung Chang ${ }^{1,2,3,6^{*}}$
}

\begin{abstract}
Background: Systemic inflammation induces neuroimmune activation, ultimately leading to sickness (e.g., fever, anorexia, motor impairments, exploratory deficits, and social withdrawal). In this study, we evaluated the role of protein kinase $\mathrm{R}(\mathrm{PKR})$, a serine-threonine kinase that can control systemic inflammation, on neuroimmune responses and sickness.

Methods: Wild-type (WT) PKR+/+ mice and PKR-/- mice were subcutaneously injected with live Escherichia coli (E. coli) or vehicle. Food consumption, rotarod test performance, burrowing, open field activity, object investigation, and social interaction were monitored. Plasma TNF-a and corticosterone were measured by ELISA. The percentage of neutrophils in blood was deduced from blood smears. Inflammatory gene expression (IL-1 $\beta$, TNF-a, IL-6, cyclooxygenase (COX)-2, iNOS) in the liver and the brain (hypothalamus and hippocampus) were quantified by real-time PCR. Blood and lavage fluid (injection site) were collected for microbiological plate count and for real-time PCR of bacterial 165 ribosomal DNA (rDNA). Corticotrophin-releasing hormone $(\mathrm{CRH})$ expression in the hypothalamus was also determined by real-time PCR.
\end{abstract}

Results: Deficiency of PKR diminished peripheral inflammatory responses following E. coli challenge. However, while the core components of sickness (anorexia and motor impairments) were similar between both strains of mice, the behavioral components of sickness (reduced burrowing, exploratory activity deficits, and social withdrawal) were only observable in PKR-/- mice but not in WT mice. Such alteration of behavioral components was unlikely to be caused by exaggerated neuroimmune activation, by an impaired host defense to the infection, or due to a dysregulated corticosterone response, because both strains of mice displayed similar neuroimmune responses, bacterial titers, and plasma corticosterone profiles throughout the course of infection. Nevertheless, the induction of hypothalamic corticotrophin-releasing hormone (CRH) by E. coli was delayed in PKR-/- mice relative to WT mice, suggesting that PKR deficiency may postpone the $\mathrm{CRH}$ response during systemic inflammation.

Conclusions: Taken together, our findings show that (1) loss of PKR could alter E. coli-induced sickness behaviors and (2) this was unlikely to be due to exacerbated neuroimmune activation, (3) elevated bacterial load, or (4) dysregulation in the corticosterone response. Further studies can address the role of PKR in the CRH response together with its consequence on sickness.

Keywords: Systemic inflammation, Neuroimmune activation, Neuroinflammation, Sickness behavior, Protein kinase $R$

\footnotetext{
* Correspondence: rccchang@hku.hk

'Laboratory of Neurodegenerative Diseases, School of Biomedical Sciences,

LKS Faculty of Medicine, The University of Hong Kong, Hong Kong SAR,

China

${ }^{2}$ Research Centre of Heart, Brain, Hormone and Healthy Aging, LKS Faculty of

Medicine, The University of Hong Kong, Hong Kong SAR, China

Full list of author information is available at the end of the article
}

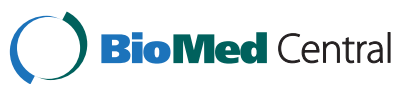

(C) 2015 Poon et al. Open Access This article is distributed under the terms of the Creative Commons Attribution 4.0 International License (http://creativecommons.org/licenses/by/4.0/), which permits unrestricted use, distribution, and reproduction in any medium, provided you give appropriate credit to the original author(s) and the source, provide a link to the Creative Commons license, and indicate if changes were made. The Creative Commons Public Domain Dedication waiver (http://creativecommons.org/publicdomain/zero/1.0/) applies to the data made available in this article, unless otherwise stated. 


\section{Background}

Sickness refers to a set of physiological and behavioral responses (e.g., fever, anorexia, immobility, reduced exploratory activity, social withdrawal, anhedonia) to systemic inflammation [1-3]. Collectively, these changes serve as the body's adaptive strategies to combat infections and injuries [4]. However, increasing lines of evidence have indicated that the same responses can become deleterious if exacerbated [1, 5-7]. Therefore, it will be beneficial to understand how sickness is regulated.

The regulation of sickness is a complex subject. Upon an inflammatory insult, innate immune cells sense pathogen-associated molecular patterns (PAMPs) and alarmins that are respectively released from pathogens and damaged tissues $[8,9]$, and respond by upregulating cytokines [10, 11], prostaglandins [12, 13], and complement factors $[14,15]$. These systemic inflammatory mediators communicate to the brain via multiple humoral and neural routes, causing neuroimmune activation and sickness [16-20]. Accordingly, inflammation is important for sickness development, and a reduction of inflammation should help to suppress sickness. Indeed, both peripheral $[10,17,21,22]$ and central [23-26] administration of exogenous inflammatory molecules acutely triggers sickness. On the contrary, pharmacological inhibition of the synthesis [27-30] or the actions [31-34] of endogenous inflammatory mediators can decrease sickness following immune challenge by lipopolysaccharide (LPS).

Protein kinase $R$ (PKR) is a ubiquitously expressed serine-threonine kinase that was originally discovered as an antiviral defense mediator $[35,36]$. Upon viral infection, PKR binds to double-stranded RNA (dsRNA) from viruses through its $\mathrm{N}$-terminal dsRNA-binding domain, resulting in PKR dimerization and autophosphorylation and activation of the C-terminal kinase domain [37-39]. Activated PKR can inhibit viral infection by phosphorylating eukaryotic initiation factor 2 (eIF2 $\alpha$ ) to decrease protein translation [40-42] and/or by inducing apoptosis of infected cells [43, 44].

Apart from its traditional antiviral roles, our group is more interested in the role of PKR in regulating inflammation. For instance, PKR can be activated during inflammation, as illustrated by an increase of PKR phosphorylation in macrophages following CD40 ligation [45] and when stimulated by toll-like receptor (TLR) ligands [46]. Furthermore, PKR shows crosstalk with inflammatory pathways such as c-Jun-N-terminal kinase (JNK) [46, 47], mitogen-activated protein kinase (MAPK) [48], nuclear factor-kappa B (NF-kB) [47, 49], signal transducers and activators of transcription 1 (STAT1) [50], interferon-regulatory factor-1 (IRF-1) [49], and inflammasome [51]. It can affect cytokine production and release from cultured fibroblasts $[47,48]$, macrophages $[46,51]$, and mixed glia/neuron co-cultures [52]. On the other hand, genetic deletion of PKR in mice attenuates plasma IL- 6 and IL-12 increases triggered by LPS [48]. Until recently, PKR has also been shown to control neuroinflammatory changes in animal models of viral encephalitis [53] and excitotoxic injury [54].

Since systemic inflammation triggers neuroimmune activation and sickness, and that PKR modulates inflammation, the purpose of this study is to investigate whether PKR can affect neuroimmune responses and sickness induced by systemic inflammatory challenge. Wild-type (WT) and PKR-/- mice were subcutaneously injected with live Escherichia coli (E. coli) or vehicle. As predicted, deficiency of PKR diminished peripheral inflammatory responses to E. coli. However, to our surprise, the loss of PKR did not decrease sickness. Instead, PKR-/- mice displayed several behavioral components of sickness (reduced burrowing, exploratory deficits, and social withdrawal) that were not observed in WT mice. Moreover, these altered sickness behaviors were unlikely to be caused by exaggerated neuroimmune activation or increased bacterial load, because both strains of mice showed similar neuroimmune responses and bacterial titers throughout the course of infection. As systemic inflammation can activate the hypothalamic-pituitary-adrenal (HPA) axis which can potentially regulate sickness [55-60], we further asked whether PKR modulates HPA axis activation following $E$. coli challenge. Both strains of mice exhibited similar changes in plasma corticosterone levels post-infection. Nevertheless, PKR-/- mice displayed a delayed induction of corticotrophin-releasing hormone $(\mathrm{CRH})$ in the hypothalamus as compared to WT mice, suggesting that the loss of PKR may postpone the CRH response to systemic inflammation. Taken together, our findings show that (1) deficiency of PKR could alter E. coli-induced sickness behaviors and (2) this was not because of exacerbated neuroimmune activation, (3) increased bacterial load, or (4) dysregulation of the corticosterone response. However, knockout of PKR could delay the CRH response to systemic inflammation, and this may possibly affect sickness.

\section{Methods}

\section{Animal husbandry}

All animal procedures were approved by the Committee on the Use of Live Animals in Teaching and Research (CULATR) of the University of Hong Kong (HKU). Wild-type C57BL/6 mice were purchased from the Laboratory Animal Unit (LAU) of the LKS Faculty of Medicine in HKU. Breeders of PKR-/- mice having targeted disruption in exons 2 and 3 of the PKR gene [61] were generously given by Prof. Bryan Williams. These mice were maintained on a C57BL/6 background prior to their arrival at our laboratory. Genome-wide single 
nucleotide polymorphism (SNP) scanning (The Jackson Laboratory, Bar Harbor, USA) also verified that $99 \%$ of the genetic makeup of PKR-/- mice is of C57BL/6. All mice were bred under a specific pathogen-free (SPF) environment maintained at $24-26{ }^{\circ} \mathrm{C}$ and under a $12: 12 \mathrm{~h}$ light:dark cycle (lights on 08:00-20:00) in LAU. Mice were used when they reached maturity at 3 months old, and only females were included to limit fighting. Individual variability in the estrous cycle was not controlled in animal husbandry. Mice were group caged (4-5 mice per cage) and provided with food and water ad libitum.

\section{Bacterial culture}

E. coli (ATCC 15746, American Type Collection, Manassa, VA) was cultured as previously described [62-64]. Briefly, after reconstituting in 35-ml brain heart infusion (BHI) broth (BD Diagnostic Systems, NJ, USA), the culture was incubated overnight at $37{ }^{\circ} \mathrm{C}, 5 \% \mathrm{CO}_{2}$. On the next day, it was supplemented with glycerol $(10 \% v / v)$, aliquoted, frozen, and stored at $-80{ }^{\circ} \mathrm{C}$. These aliquots served as glycerol stocks. Typically, on the day before injection, $0.5 \mathrm{ml}$ of glycerol stock was used to inoculate $35 \mathrm{ml} \mathrm{BHI}$ and grown overnight as described above. The bacterial concentration was quantified by measuring its absorbance at $595 \mathrm{~nm}$ and extrapolating from a previously determined standard curve. The bacteria were centrifuged at $4000 \times g$ for $30 \mathrm{~min}$, the supernatant was removed, and the bacterial pellet was re-suspended in sterile phosphate buffered saline (PBS).

\section{Experimental paradigm}

Four days before the injection, mice were transferred from LAU to an isolated behavioral testing room that was maintained at $24-26{ }^{\circ} \mathrm{C}$ and under a $10: 14 \mathrm{~h}$ light:dark cycle (lights on 09:00-19:00). A small area of hair, i.e., $1 \times 1 \mathrm{~cm}$, was shaved from the back (i.e., just caudal to the ears) of each mouse to facilitate inspection of local inflammation. Mice were then singly caged, and allowed to habituate for 4 days in the behavioral room. On the day after the habituation period, mice were either injected with $0.5 \mathrm{ml}$ sterile PBS (vehicle) or $8 \times 10^{8}$ colony-forming unit (CFU) E. coli. This dose was chosen based on our preliminary observations that it can produce obvious signs of sickness (e.g., anorexia, decreased activity) in mice for several days without causing severe mortality (mortality rate was below $1 \%$ ) or extreme weight loss (weight loss was less than $10 \%$ of the starting body weight). All injections took place at 11:00-12:00, and mice were monitored for the next $120 \mathrm{~h}$.

\section{Food consumption}

The amount of food given to each mouse (placed on the cage top) was pre-weighed, and the amount remaining $24 \mathrm{~h}$ later was weighed again. The amount of food consumed in a day was calculated by the difference between the two masses. Any food material that was not consumed in the previous day was discarded to minimize spill over to the next day.

\section{Rotarod test}

The rotarod test was performed as previously described but with some minor modifications [65]. Briefly, the apparatus consisted of a horizontal rotatable rod $(10 \mathrm{~cm}$ long, $6 \mathrm{~cm}$ in diameter) surrounded by vertical boards to prevent animal escape. A padding material (a stack of plastic bags) was placed at the bottom of the setup to minimize animal injury when the animal falls from the rod. A mouse was placed with its front paws just touching the rotating rod and immediately released. The speed of rotation was gradually accelerated, and the time of which the mouse stayed on the rod before falling was recorded. Mice staying for more than 3 min were counted as staying for $3 \mathrm{~min}$. Each mouse was given three trials each time, and the average of the three readings was used for data analysis. Mice were trained for the rotarod test on two different days of the habituation period to acclimatize them to the procedure, and tested at 24 and $96 \mathrm{~h}$ after the injection.

\section{Burrowing}

Burrowing is a rodent-specific behavior, and this behavior has been used to study sickness [11, 27, 28]. This setup consisted of an opaque and hollow plastic tube $(6 \times 6 \times 15 \mathrm{~cm})$, sealed at one end and with the other end being tilted at an angle such that it could stand $1 \mathrm{~cm}$ above the cage floor. It was filled with a bedding material ( $\sim 60 \mathrm{~g})$, and together they were pre-weighed. The tube was then introduced into the cage, and the mouse was allowed to burrow while the experimenter remained outside the room. One hour after testing, the tube and its contents were weighed again, and the amount of bedding material burrowed was calculated by the difference between the two readings. Mice were trained to burrow during the habituation period to limit inter-individual variation in baseline burrowing activity and were tested every $24 \mathrm{~h}$ after the injection.

\section{Open field test}

The open field test [66] was conducted in a $40 \mathrm{~cm}$ $(\mathrm{L}) \times 30 \mathrm{~cm}(\mathrm{~W}) \times 40 \mathrm{~cm}(\mathrm{H})$ white plastic arena, with a floor that was gridded into 12 equal $10 \times 10 \mathrm{~cm}$ squares. A mouse facing at a corner of the arena, and having its front paws just touching the arena floor, was quickly released. It was allowed to explore the open field for $3 \mathrm{~min}$, during which its behavior was videotaped. Testing was performed under quiet and dim lighting, and the experimenter remained outside the behavioral room throughout the test. The number 
of lines crossed by the mouse in this novel environment was determined from the video, and validated by an independent experimenter. Testing was performed at $120 \mathrm{~h}$ post-injection.

\section{Object investigation test}

Immediately after the open field test, the mouse was temporarily returned to its home cage, and two identical transparent plastic cages, i.e., $8 \mathrm{~cm}(\mathrm{~L}) \times 6 \mathrm{~cm}(\mathrm{~W}) \times 12 \mathrm{~cm}(\mathrm{H})$ and having holes on its sides, were placed one on each side ( $6 \mathrm{~cm}$ side) of the arena. The mouse was introduced back into the arena, with its head facing the wall of one of the $8-\mathrm{cm}$ sides and its front paws just touching the floor, and immediately released. It was allowed to explore the two transparent cages for $3 \mathrm{~min}$, during which it was videotaped. The experimenter remained outside the room. The amount of time the mouse spent investigating both novel cages was determined from the videotape and validated by another independent experimenter. A mouse was regarded as interacting with the cage if it (1) physically contacted with the cage or if (2) its nose was $2 \mathrm{~cm}$ near the cage. Any accidental bumping of the mouse to the cage by its limbs or its body was not regarded as interaction. One $E$. coli-injected PKR-/- mice jumped onto a cage and remained there for the whole period, and hence it was not included in the data analysis.

\section{Social interaction test}

The social interaction test was conducted similarly as reported but with some modifications [67]. Immediately following the object investigation test, the mouse was returned back to its home cage, and a novel female C57BL/6 mouse ( 3 weeks old) was put into one of the two empty cages. The subject mouse was introduced back into the arena in the same way as above. The behavior of the mouse was recorded for the next $3 \mathrm{~min}$. The time that the subject mouse spent interacting with the empty cage and the time that it spent interacting with the social cage were both deduced from the video and validated by an independent experimenter. Five mice jumped onto a cage and were rejected for data analysis. After the test, the entire apparatus was washed with running tap water, wiped with towel, and allowed to dry before testing the next mouse. The same novel mouse was used across all subject mice.

\section{Total RNA extraction, genomic DNA digestion, and reverse transcription}

Mice were sacrificed with an overdose of sodium pentobarbital $(100 \mathrm{mg} / \mathrm{kg})$. The liver and brain were quickly collected, and the hypothalamus (within Bregma 0.86 to $-2.7 \mathrm{~mm}$ ) and hippocampus (within Bregma -0.82 to $-3.8 \mathrm{~mm}$ ) were isolated on ice. Total RNA was extracted using TRI Reagent ${ }^{\circ}$ RT (Molecular Research
Centre Inc, Cincinnati, USA) according to the manufacturer's protocol. The RNA concentrations in the samples were quantified by NanoDrop 2000c (Thermo Scientific, Wilmington, USA). All RNA samples had A260/A280 ratios of 1.8-2.0 and showed distinct bands for the $28 \mathrm{~S}$ and $18 \mathrm{~S}$ rRNA subunits on a gel. To remove any contaminating genomic DNA, $4 \mu \mathrm{g}$ total RNA from each sample was treated with DNA-free ${ }^{\text {tw }}$ DNA Removal Kit (Life Technologies, Carlsbad, USA) in a $22-\mu \mathrm{l}$ reaction volume, and $8 \mu \mathrm{l}$ of the reaction $(\sim 1.45 \mu \mathrm{g}$ total RNA) was taken for reverse transcription by SuperScript ${ }^{\text {tw }}$ III First-Strand Synthesis system (Life Technologies, Carlsbad, USA). cDNA samples were $10 \times$ diluted in DEPC-treated water.

\section{Real-time PCR}

Two microliters of diluted cDNA was amplified in triplicate with SYBR Premix Ex Taq ${ }^{\text {Tix }}$ II kit, Perfect Real Time (Takara Bio Inc, Shiga, Japan) and employing the $\mathrm{MyiQ}^{\mathrm{Tm}} 2$ two-color Real-Time PCR detection System (Bio-Rad, Hercules, USA). The general PCR protocol was as follows: $95{ }^{\circ} \mathrm{C}$ for $120 \mathrm{~s}, 95{ }^{\circ} \mathrm{C}$ for $15 \mathrm{~s}$, annealing temperature (refer to Table 1) for $30 \mathrm{~s}$, and $72{ }^{\circ} \mathrm{C}$ for $10-30 \mathrm{~s}$ (see Table 1) for 45 cycles. The specificity of PCR was confirmed by ensuring that there was only one peak in the melting curve analysis and only one band matching to the size the PCR product on a gel. All PCR amplification efficiencies were $90-110 \%$. The expression level of each mouse gene was extrapolated from the standard curve and normalized to the expression level of a housekeeping gene glyceraldehyde 3-phosphate dehydrogenase (GAPDH). Our preliminary results indicated that GAPDH expression was unaffected by genotype or by $E$. coli in the brain and liver. Results for the mouse genes were reported as relative mRNA expression. Results of $16 \mathrm{~S}$ ribosomal DNA (rDNA) do not require the normalization step and were reported as fold of the WT PBS group.

\section{Assessment of blood neutrophil percentage}

An increase of blood neutrophil granulocytes can serve as an indicator of systemic inflammation [68]. To assess this, whole blood was collected from mice by making a tail nick. Twenty microliters of blood was spotted onto a glass slide to produce a blood smear, and three blood smears were prepared per mouse. Slides were fixed in methanol for $30 \mathrm{~s}$ and allowed to dry under room temperature. They were stained with $5 \%$ Giemsa stain, pH 6.8 (Medical Chemical Corporation, Torrance, USA) for $20 \mathrm{~min}$ and briefly washed in deionized water. Next, they were dehydrated in a graded series of ethanol, cleared in toluene, mounted with Permount (Sigma Aldrich, St. Louis, USA), and coverslipped. Slides were viewed under a $40 \times$ objective of a Zeiss Axiophot microscope (Carl Zeiss, Thornwood, USA) connected to a 
Table 1 The PCR conditions for IL-1 $\beta$, TNF-a, IL-6, COX-2, iNOS, CRH, GAPDH, and $16 \mathrm{~S}$ rDNA

\begin{tabular}{|c|c|c|c|c|c|}
\hline Gene & Primer sequences & $\begin{array}{l}\text { Working primer } \\
\text { concentration }(\mu \mathrm{M})\end{array}$ & $\begin{array}{l}\text { Annealing } \\
\text { temperature }\left({ }^{\circ} \mathrm{C}\right)\end{array}$ & $\begin{array}{l}\text { Extension } \\
\text { time (s) }\end{array}$ & $\begin{array}{l}\text { Amplicon size } \\
\text { (base pair) }\end{array}$ \\
\hline \multirow[t]{2}{*}{ IL-1 $\beta(118130747)$} & F: 5'-CCTCCTTGCCTCTGATGG-3' & 0.4 & 60 & 10 & 99 \\
\hline & R: 5'-AGTGCTGCCTAATGTCCCC-3' & & & & \\
\hline \multirow[t]{2}{*}{ TNF-a (518831586) } & F: 5'-CCCCAGTCTGTATCCTTCT-3' & 0.4 & 59 & 30 & 106 \\
\hline & R: 5'-ACTGTCCCAGCATCTTGT-3' & & & & \\
\hline \multirow[t]{2}{*}{ IL-6 (13624310) } & F: 5'-GGCAATTCTGATTGTATG-3' & 0.4 & 56 & 30 & 208 \\
\hline & R: 5'-CTCTGGCTTTGTCTTTCT-3' & & & & \\
\hline \multirow[t]{2}{*}{ COX-2 (118130137) } & F: 5'-GATGACTGCCCAACTCCC-3' & 0.25 & 60 & 10 & 191 \\
\hline & R: 5'-AACCCAGGTCCTCGCTTA-3' & & & & \\
\hline \multirow[t]{2}{*}{ iNOS (146134510) } & F: 5'-AAACGCTTCACTTCCAATG-3' & 0.4 & 61 & 30 & 296 \\
\hline & R: 5'-CAATCCACAACTCGCTCC-3' & & & & \\
\hline \multirow[t]{2}{*}{ CRH (292781723) } & F: 5'-GTGCGGGCTCACCTACCAA-3' & 0.4 & 57 & 10 & 107 \\
\hline & R: 5'-AGGCAGGCAGGACGACAGA-3' & & & & \\
\hline \multirow[t]{2}{*}{ GAPDH (576080554) } & F: 5'-ATTCAACGGCACAGTCAA-3' & 0.4 & 56 & 10 & 77 \\
\hline & R: 5'-CTCGCTCCTGGAAGATGG-3' & & & & \\
\hline \multirow[t]{2}{*}{ 16S rDNA (J01859.1) } & F: 5'-GCAAGCGGACCTCATAAA-3' & 0.25 & 54 & 20 & 100 \\
\hline & R: 5'-ATTCACCGTGGCATTCTG-3' & & & & \\
\hline
\end{tabular}

The real-time PCR conditions for IL-1 $\beta$, TNF- $a$, IL-6, COX-2, iNOS, CRH, GAPDH, and 16S rDNA. Accession numbers from the Genebank are shown in brackets. COX-2 cyclooxygenase-2, CRH corticotrophin-releasing hormone, iNOS inducible nitric oxide synthase, TNF- $a$ tumor necrosis factor- $a$, IL interleukin

SPOT RT3 ${ }^{\mathrm{Tm}}$ camera (SPOT Imaging Solutions, Sterling Heights, USA). Ten bright view images were captured at the "zone of morphology" in each slide, and three slides per mouse. The numbers of neutrophils and leukocytes were manually counted. Neutrophil \% was calculated by Neutrophil \% = (Average no. of neutrophils/Average no. of leukocytes) $\times 100 \%$.

\section{Determination of bacterial titer}

Bacterial titers at the injected site and in blood were quantified every $24 \mathrm{~h}$ by microbiological plate count and by real-time PCR for bacterial $16 \mathrm{~S}$ rDNA. Briefly, lavage fluid was collected by subcutaneously injecting $1 \mathrm{ml}$ of sterile phosphate buffered saline (PBS) at the injection site and immediately withdrawing $\sim 200 \mu \mathrm{l}$ using another pair of sterile needle and syringe. Blood was obtained by making a tail nick as described above and supplemented with sterile disodium EDTA (3.6 mM) for anti-coagulation. For the plate count method, blood and lavage samples were serially diluted with sterile PBS. The diluted samples were spread onto pre-warmed lysogeny broth (LB) agar plates (BD Diagnostic Systems, NJ, USA) and incubated at $37^{\circ} \mathrm{C}$. After $24 \mathrm{~h}$, the number of colonies was counted by two independent observers, and the corresponding bacterial titer in the undiluted sample was calculated. The $16 \mathrm{~S}$ rDNA method was performed as previously described but with a few minor modifications [69]. In brief, $20 \mu \mathrm{l}$ of lavage fluid and $50 \mu \mathrm{l}$ of anti-coagulated blood were respectively treated with 25 and $65 \mathrm{U}$ of mutanolysin (Sigma Aldrich, St. Louis, USA) at $37^{\circ} \mathrm{C}$ for $30 \mathrm{~min}$. Genomic DNA was purified from the mutanolysin-treated samples using the QIAamp DNA Mini kit (Qiagen Inc., Valencia, CA) based on the manufacturer's protocol and eluted in $100 \mu \mathrm{l}$ of double distilled water. Two microliters of the elution was used for real-time PCR for 16S rDNA as described before.

\section{TNF- $a$ and corticosterone ELISA}

Mice were sacrificed with an overdose of sodium pentobarbital $(100 \mathrm{mg} / \mathrm{kg})$ at $4 \mathrm{~h}(16: 00)$ and $48 \mathrm{~h}$ (12:00). Heparinized blood was collected by cardiac puncture, centrifuged, and the plasma was removed and stored at $-80{ }^{\circ} \mathrm{C}$ until analysis. TNF- $\alpha$ and corticosterone levels were determined using Mouse TNF-alpha DuoSet ELISA Kit (R\&D systems Inc, Minneapolis, Canada) and Corticosterone EIA Kit (Cayman Chemical Company, Ann Arbor, USA), respectively, according to the manufacturers' instructions. For the ELISA of corticosterone, plasma samples were first $200 \times$ diluted in assay buffer. The detection limit of the TNF- $\alpha$ ELISA assay was $31 \mathrm{pg} / \mathrm{ml}$, and that of the corticosterone ELISA assay was $30 \mathrm{pg} / \mathrm{ml}$ (i.e., $6 \mathrm{ng} / \mathrm{ml}$ in the undiluted sample).

\section{Data and statistical analysis}

Statistical analysis was conducted by SigmaStat $^{\circledR} 3.0$ (Jandel Scientific, San Rafael, USA). Data for food consumption, burrowing, and the rotarod test were analyzed by two-way repeated measures of analysis of variance (ANOVA) with genotype (WT E. coli v.s. PKR-/- E. coli) and time as the main factors. If a significant interaction effect could be detected, Bonferroni post hoc comparison 
was performed. Additionally, selected time points for food consumption and the rotarod test were analyzed by oneway ANOVA followed by Student-Newman-Keuls post hoc comparison. The open field test, object investigation test, and social interaction test were replicated in two independent batches of experiments (including all four treatment groups in each batch). For the open field and object investigation tests, data were first expressed as fold of the WT PBS group of the same batch of experiment before both batches were combined for data analysis. They were then analyzed by one-way ANOVA followed by Student-Newman-Keuls post hoc comparison. For the social interaction test, data from the same experiment were expressed as fold of interaction with the social cage of the WT PBS group, and data from both batches were pooled. Interaction effect between experimental group (WT or PKR-/- mice injected with PBS or E. coli) and cage (social v.s. empty) was analyzed by two-way ANOVA, followed by, if significant, Bonferroni post hoc comparison. Data including all four experimental groups (WT PBS, WT E. coli, PKR-/- PBS, PKR-/- E. coli) for real-time PCR, neutrophil \%, and ELISA were analyzed by oneway ANOVA followed by Student-Newman-Keuls post hoc comparison. Additionally, two-tailed $t$ tests were performed to analyze for potential differences in baseline corticosteroid levels across time $(4 \mathrm{~h}$ WT PBS v.s. 48 h WT PBS; 4 h PKR-/- PBS v.s. 48 h PKR-/- PBS). Data of bacterial plate count and $16 \mathrm{~S}$ rDNA were positively skewed and were thus log transformed [70]. Transformed data were analyzed by twoway ANOVA with genotype (WT E. coli v.s. PKR-/E. coli) and time as the main factors. All values were represented as mean \pm standard error from the mean (SEM), and results were considered significantly different if $p<0.05$.

\section{Results \\ PKR-I- mice displayed altered E. coli-induced sickness behaviors}

Systemic inflammation induces both core (e.g., fever, anorexia, motor impairments) and behavioral (e.g., social withdrawal, reduced exploration, anhedonia, cognitive deficits) components of sickness [5, 19, 71]. As PKR has been known to regulate inflammation [36, 72], we evaluated whether loss of PKR would also affect these two components of sickness.

Deficiency of PKR did not affect the core components of sickness. For example, WT and PKR-/- mice displayed similar reductions in food consumption after $E$. coli, and these changes were gradually restored by day 3 (Fig. 1a). Two-way repeated measures ANOVA of the E. colitreated groups did not indicate any interaction effect $(F=0.749$, df 4, 60, $p=0.563$ ) between genotype (WT E. coli or PKR-/-E. coli) and the time post-injection, implying that the genotype had no effect on the anorexic responses across time. As further supportive evidence, one-way ANOVA followed by Student-Newman-Keuls post hoc comparison showed that E. coli was able to decrease $(p<0.001)$ food consumption in WT mice (WT PBS v.s. WT E. coli) and PKR-/- mice (PKR-/- PBS v.s. PKR $-/-E$. coli) on day 1 and day 2 , but no difference $(p>0.05)$ could be found between the E. coli-challenged groups on both days. Likewise, both strains of mice showed similar motor impairments in the rotarod test following E. coli (Fig. 1b). Two-way repeated measures ANOVA of the E. coli-challenged groups did not show any interaction between genotype and time $(F=0.0753$, df 2, 27, $p=0.0928)$. Moreover, one-way ANOVA with Student-Newman-Keuls post hoc test indicated that $E$. coli decreased motor performance $(p<0.05)$ in WT and PKR $-/-$ mice at $24 \mathrm{~h}$, but again there was no difference $(p=0.822)$ between the E. coli-treated groups.

Although the core components of sickness were similar between WT and PKR-/- mice, the behavioral components of sickness were altered in PKR-/- relative to WT mice. As shown in Fig. 1c, E. coli reduced burrowing in PKR-/mice but not in WT mice. Two-way repeated measures ANOVA of the E. coli-challenged groups indicated a main effect of genotype $(F=9.002$, df $1,75, p=0.009)$ and an interaction between genotype and time $(F=2.796$, df 5,75 , $p=0.023$ ), suggesting that the effect of genotype on the burrowing deficits depended on the time post-injection. Bonferroni post hoc comparison showed that the PKR-/$E$. coli group had significantly lesser burrowing activity than the WT E. coli group at $7 \mathrm{~h}(p<0.001)$ and $24 \mathrm{~h}$ $(p=0.001)$. In addition, at $120 \mathrm{~h}$ post-injection, a time when the core components of sickness had disappeared in both strains of mice, PKR-/- mice still displayed reduced exploratory activities in the open field test (Fig. 1d) and object investigation test (Fig. 1e). One-way ANOVA followed by Student-Newman-Keuls post hoc test showed that $E$ coli significantly decreased $(p<0.05)$ the exploratory activities of PKR $-/-$ mice (PKR-/- PBS v.s. PKR-/-E. coli) in both tasks and that the PKR-/-E. coli group also explored significantly lesser as compared to the WT E. coli group. Finally, we found that $E$. coli triggered social withdrawal in PKR-/- mice but not in WT mice at $120 \mathrm{~h}$ (Fig. 1f). Two-way ANOVA with cage (social v.s. empty) and experimental grouping (WT PBS/WT E. coli/PKR-/$\mathrm{PBS} / \mathrm{PKR}-/-E$. coli) as the main factors indicated a main effect of cage $(F=60.489$, df $1,96, p<0.001)$ and an interaction between cage and experimental group $(F=3.044$, df $3,96, p<0.033)$. Hence, the effect of the social cage depended on the experimental group. Bonferroni post hoc comparison found significant differences $(p<0.001)$ between social v.s. empty cages in 


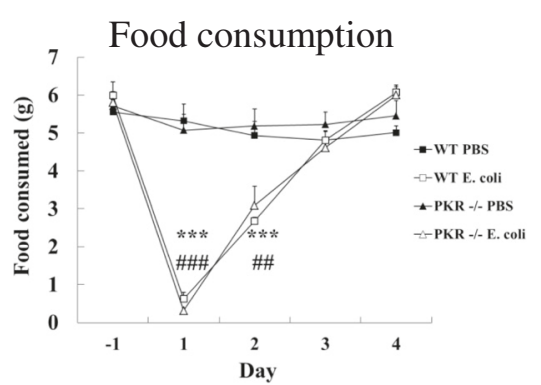

(a)

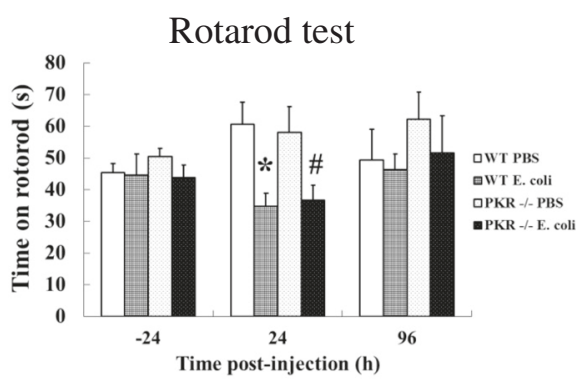

(b)

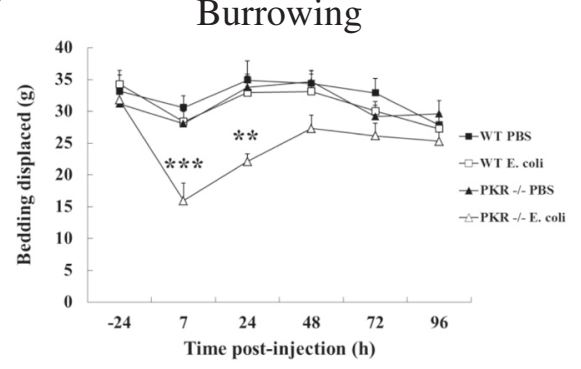

(c)

Open field test

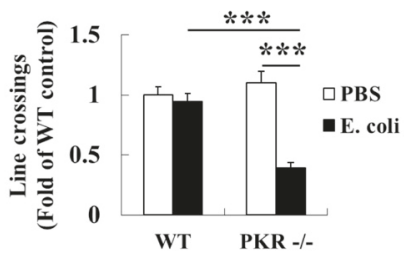

(d)
Object investigation test

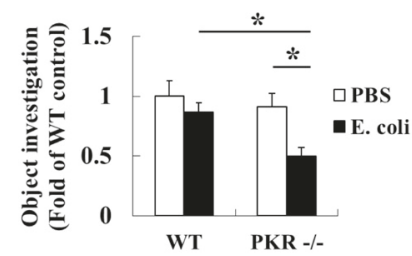

(e)

Social interaction test

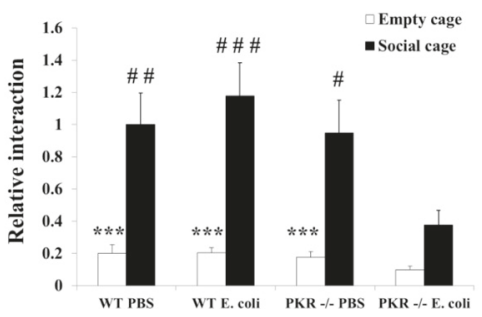

(f)

Fig. 1 Effects of PKR deficiency on E. coli-induced sickness. WT and PKR-/- mice were subcutaneously challenged by E. coli or PBS, and sickness responses were monitored for the next $120 \mathrm{~h}$. Infection of E. coli led to similar decreases in food consumption (a) and rotarod test performance (b) in WT and PKR-/- mice. * $p<0.05,{ }^{* * *} p<0.001$, WT E. coli versus WT PBS; $+p<0.05,+++p<0.001$, PKR E. coli versus PKR PBS; $n=8$ per group. However, E. coli suppressed burrowing in PKR $-/-$ mice but not in WT mice (c). ${ }^{* *} p<0.01,{ }^{* * *} p<0.001$, PKR $-/-E$. coli versus PKR $-/-$ PBS, $n=8$ per group. Furthermore, at $120 \mathrm{~h}$ post-injection, E. coli downregulated open field (d) and object investigation (e) activities in PKR-/- mice but not in WT mice. ${ }^{*} p<0.05,{ }^{* * *} p<0.001 ; n=13-16$ per group. Likewise, E. coli decreased social interaction in PKR-/- mice but not in WT mice at

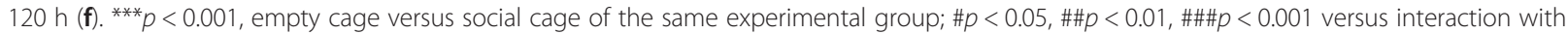
the social cage of the PKR-/-E. coli group; $n=12-15$ per group

the WT PBS, WT E. coli, and PKR-/- PBS groups, but not in the PKR $-/-E$. coli group $(p=0.099)$. The investigation of the social cage in the PKR $-/-E$. coli group was also significantly lesser than that of the other three experimental groups $(p<0.05)$.
PKR-/- mice displayed reduced peripheral inflammatory responses to $E$. coli

A previous study has demonstrated that genetic deficiency of PKR can attenuate plasma cytokine increases following systemic LPS challenge [48]. Hence, it would 
be reasonable to postulate that loss of PKR should similarly reduce peripheral inflammatory changes after a subcutaneous injection of $E$. coli. However, since only PKR-/- mice developed observable behavioral components of sickness, we first questioned whether genetic deletion of PKR would unexpectedly promote peripheral inflammation in response to an $E$. coli infection.

Consistent with the earlier study [48], PKR-/- mice showed diminished peripheral inflammatory responses to E. coli. Genetic deletion of PKR suppressed inflammatory gene induction (IL-1 $\beta$, TNF- $\alpha$, IL-6, cyclooxygenase (COX)-2, iNOS) in the liver (Fig. 2), where the highest density of tissue macrophages, i.e., Kupffer cells, reside in the body [73]. Particularly at $4 \mathrm{~h}$, post hoc StudentNewman-Keuls test after one-way ANOVA showed that E. coli upregulated $(p<0.01)$ all five inflammatory genes in both strains of mice, but the induction in PKR $-/-$ mice was significantly lower $(p<0.05)$ than that of WT mice. At $48 \mathrm{~h}$, the levels of IL-1 $\beta$, TNF- $\alpha$, and iNOS still remained elevated $(p<0.01)$ by $E$. coli, but there was no

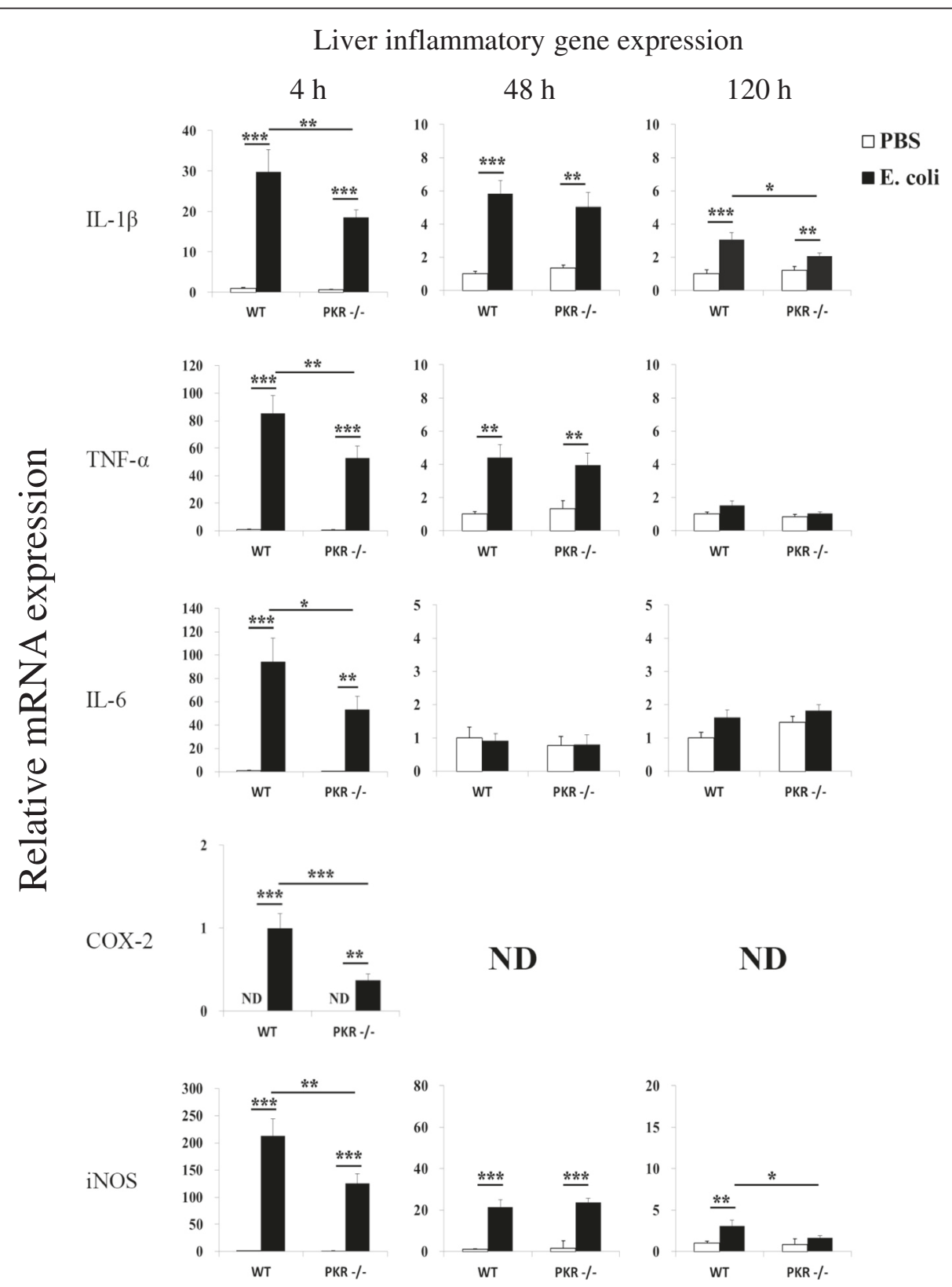

Fig. 2 Relative mRNA expression profiles of IL-1 $\beta$, TNF-a, IL-6, COX-2, and iNOS in the liver. Loss of PKR inhibited inflammatory gene expression in the liver triggered by E. coli, particularly at 4 h. $n=7-8$ per group at $4 \mathrm{~h}, n=6-8$ per group at $48 \mathrm{~h}$, and $n=9-11$ per group at $120 \mathrm{~h}$. ND not detectable; ${ }^{*} p<0.05,{ }^{* *} p<0.01,{ }^{* * *} p<0.001$ 
significant difference $(p>0.05)$ between the E. coli-treated groups. At $120 \mathrm{~h}$, even smaller increases $(p<0.05)$ of IL$1 \beta$ (WT and PKR-/- mice) and iNOS (WT mice only) were detected, and the expression of these genes were significantly lower $(p<0.05)$ in the PKR-/ $-E$. coli group than in the WT E. coli group. In line with these findings, deficiency of PKR led to a lesser increase of plasma TNF- $\alpha$ at $4 \mathrm{~h}$ after $E$. coli challenge (Fig. 3a). In the PBS-injected groups, plasma TNF- $\alpha$ levels were below the detection limit $(<31 \mathrm{pg} / \mathrm{ml})$ of the ELISA assay. One-way ANOVA followed by Student-Newman-Keuls post hoc test indicated that E. coli elevated plasma TNF- $\alpha$ in WT mice (WT PBS v.s. WT E. coli; $p<0.001$ ) and PKR-/- mice (PKR-/- PBS v.s. PKR-/-E. coli; $p<0.001$ ) and that the PKR-/- E. coli group had a lower level of TNF- $\alpha$ than the WT E. coli group (WT E. coli v.s. PKR-/- E. coli; $152 \pm 24$ v.s. $88 \pm 17 \mathrm{pg} / \mathrm{ml} ; p=0.003)$. Finally, an elevation of neutrophil granulocytes in blood can serve as an index of systemic inflammation [68]. We found that deficiency of PKR in mice triggered a smaller increment of neutrophil \% at $120 \mathrm{~h}$ post-injection (Fig. 3b). One-way ANOVA followed by Student-Newman-Keuls post hoc comparison showed that E. coli upregulated neutrophil \% in both WT mice (WT PBS v.s. WT E. coli; $18.5 \pm 2.1$ v.s. $46.7 \pm 3.1 \%$; $p<0.001$ ) and PKR-/- mice (PKR-/- PBS v.s. PKR-/-E. coli; $21.2 \pm 2.7$ v.s. $38.1 \pm 2.2 \% ; p<0.001$ ), and also a lower neutrophil \% was seen in the PKR-/-E. coli group than in the WT E. coli group ( $p=0.028)$.

\section{Neuroimmune responses in WT and PKR-/- mice were similar}

Since peripheral inflammatory changes were suppressed in $\mathrm{PKR}-/$ - mice, we asked whether neuroimmune responses would also be dampened in PKR-/- mice. Therefore, we assessed inflammatory gene expression in the hypothalamus and hippocampus after E. coli challenge in WT and PKR-/- mice. These two brain regions were selected for analysis because of their high expression for cytokine receptors in the brain [74-76] and that they are important in the control of the sickness [2]. To

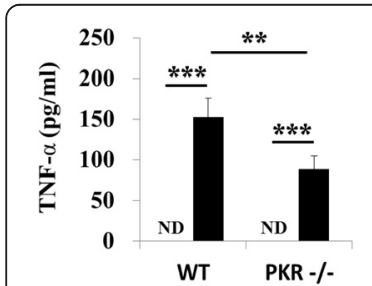

(a)

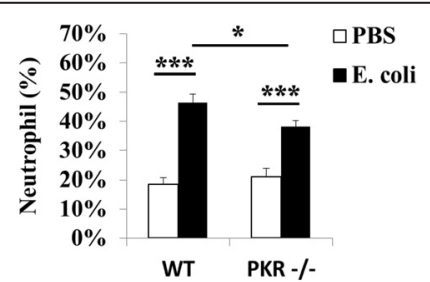

(b)
Fig. 3 Deficiency of PKR led to smaller increases of plasma TNF-a and neutrophil \%. Peripheral blood was collected at $4 \mathrm{~h}$ for TNF-a ELISA (a) and at $120 \mathrm{~h}$ (b) for peripheral leukocyte count after the injection of PBS or E. coli. $n=8-10$ per group in $\mathbf{a}$, and $n=13-16$ per group in b. ND not detectable; ${ }^{*} p<0.05,{ }^{* *} p<0.01,{ }^{* * *} p<0.001$ our surprise, we found that both strains of mice displayed mostly similar increases of inflammatory genes at both brain regions.

At $4 \mathrm{~h}$ in the hypothalamus (Fig. 4), E. coli significantly upregulated mRNA expression for IL-1 $\beta$, TNF- $\alpha$, IL-6, and COX-2 in WT and PKR-/- mice $(p<0.05$, one-way ANOVA followed by Student-Newman-Keuls post hoc test), but no significant difference could be detected $(p>0.05)$ between the E. coli-challenged groups for all four genes. On the other hand, E. coli led to a small drop $(\sim 30 \%, p<0.05)$ in iNOS mRNA expression in PKR-/- mice (PKR-/- PBS v.s. PKR-/-E. coli), and the $\mathrm{PKR}-/-E$. coli group also showed significantly lesser expression of iNOS $(p<0.05)$ than the WT $E$. coli group. At $48 \mathrm{~h}, E$. coli was still able to elevate IL$1 \beta$, TNF- $\alpha$, and COX-2 expression $(p<0.01)$ in both genotypes of mice, and it also increased iNOS expression $(p<0.01)$ in WT mice. Among these genes, the PKR-/-E. coli group displayed significantly lower expression for TNF- $\alpha(p<0.01)$ and iNOS $(p<0.05)$ than the WT E. coli group. IL-6 mRNA was similarly reduced by $E$. coli in both strains of mice $(p<0.001)$, and no significant difference was found between the $E$. coli-treated groups. At $120 \mathrm{~h}$, small increases of TNF$\alpha$ (both genotypes, $p<0.05$ ) and IL-1 $\beta$ (WT mice only, $p<0.05)$ could still be observed, but no significant difference $(p>0.05)$ could be found among the $E$. colitreated groups for both genes.

Similarly, at $4 \mathrm{~h}$ in the hippocampus (Fig. 5), E. coli upregulated the mRNA expression of IL- $1 \beta$, TNF- $\alpha$, IL- 6 , and COX-2 $(p<0.05)$ in WT and PKR-/- mice, but no significant difference $(p>0.05)$ was found between the E. colichallenged groups of the two strains of mice. Likewise, at $48 \mathrm{~h}$, there were still small increases (i.e., less than onefold, $p<0.05)$ in the mRNA expression of IL-1 $\beta$ and COX-2 (WT and PKR-/- mice), TNF- $\alpha$ (PKR-/- mice only), and iNOS (WT mice only), but none of these inflammatory genes displayed any significant difference $(p>0.05)$ between the E. coli-treated groups. At the same time point, IL-6 expression was decreased in both genotypes by $E$. coli $(p<0.001)$, but the $E$. coli-treated groups did not differ in IL-6 expression. Finally, at $120 \mathrm{~h}$, only a small increase of TNF- $\alpha(\sim 40 \%, p<0.01)$ was observed in PKR-/- mice after $E$. coli, but this also did not reach statistical difference $(p=0.11)$ when compared to the WT E. coli group.

Bacterial titers were similar between WT and PKR-/- mice Given that loss of PKR in mice reduced peripheral inflammatory responses but at the same time led to more observable behavioral components of sickness, we questioned whether PKR deficiency had exaggerated bacterial load. By performing standard microbiological plate counts and real-time PCR for bacterial $16 \mathrm{~S}$ rDNA, we 


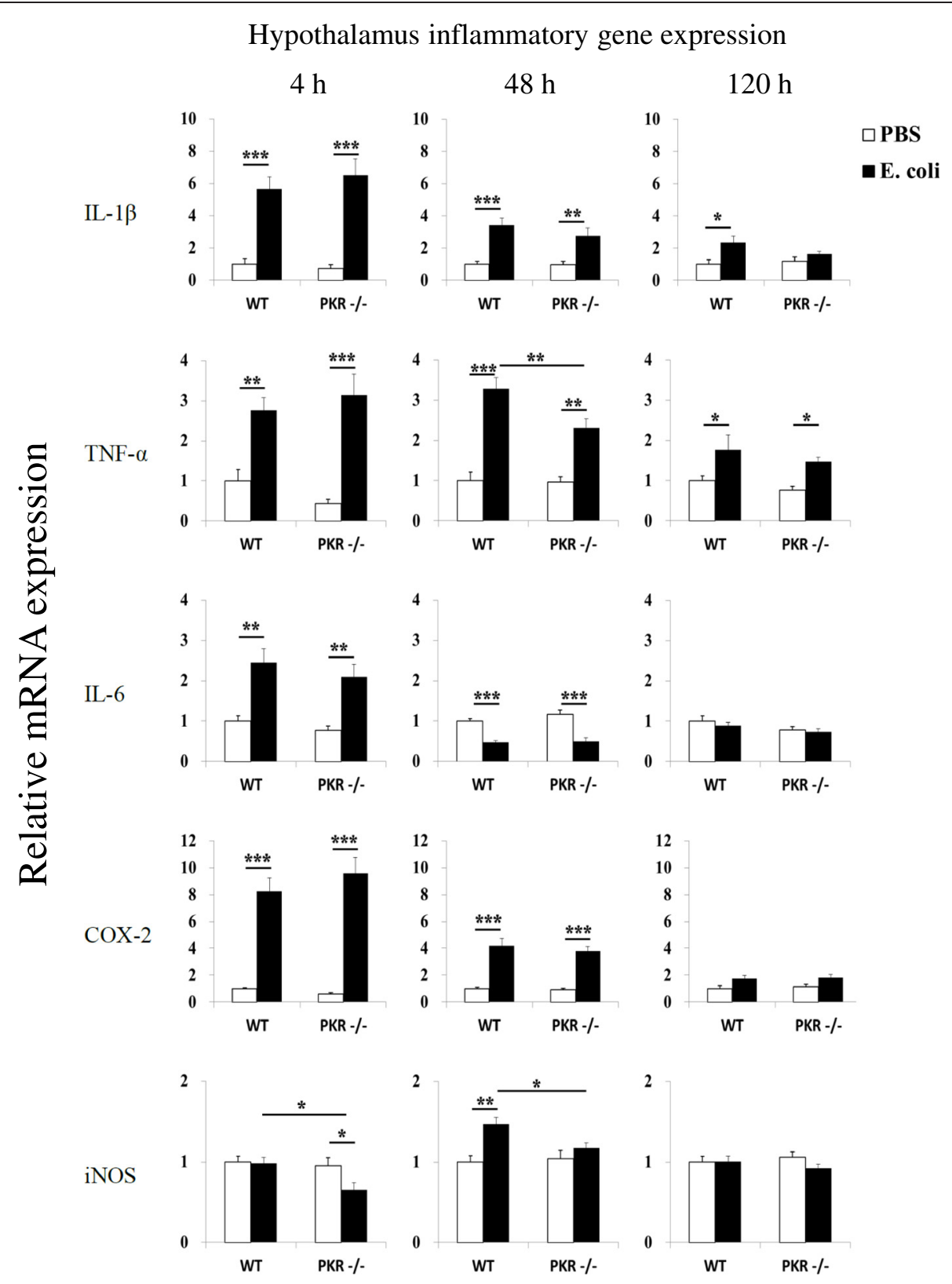

Fig. 4 Relative mRNA expression profiles of IL-1 $\beta$, TNF- $a, I L-6, C O X-2$, and iNOS in the hypothalamus. The loss of PKR had little effect on inflammatory gene expression in the hypothalamus after E. coli challenge. $n=7-8$ per group at $4 \mathrm{~h}, n=6-8$ per group at $48 \mathrm{~h}$, and $n=9-11$ per group at the $120 \mathrm{~h}$ time point. ${ }^{*} p<0.05,{ }^{* *} p<0.01,{ }^{* * *} p<0.001$

found that the changes of bacterial titers were similar between the two strains of mice at the injection site (i.e., lavage fluid) and in blood throughout the course of infection.

For the plate count method, we observed that lavage fluid from the PBS-injected mice of both strains did not produce any colonies, thus ruling out the possibility of sample contamination during the procedure. However, lavage fluid from the E. coli-injected mice gave rise to numerous bacterial colonies (Fig. 6a). Two-way ANOVA of the $\log$ transformed data indicated a main effect of time $(F=4.206$, df $4149, p=0.003)$ on the level of colony-forming units (CFU), but no interaction could be detected between genotype (WT E. coli v.s. PKR-/- E. coli) and time $(F=0.838, \mathrm{df} 4,149, p=0.503)$. Hence, although bacterial titers varied with time, genotype had no effect on the change of bacterial titers across time. Moreover, we did not recover any bacterial colonies from the blood samples of the bacterial challenged mice at any of the time points included, suggesting that the $E$. 


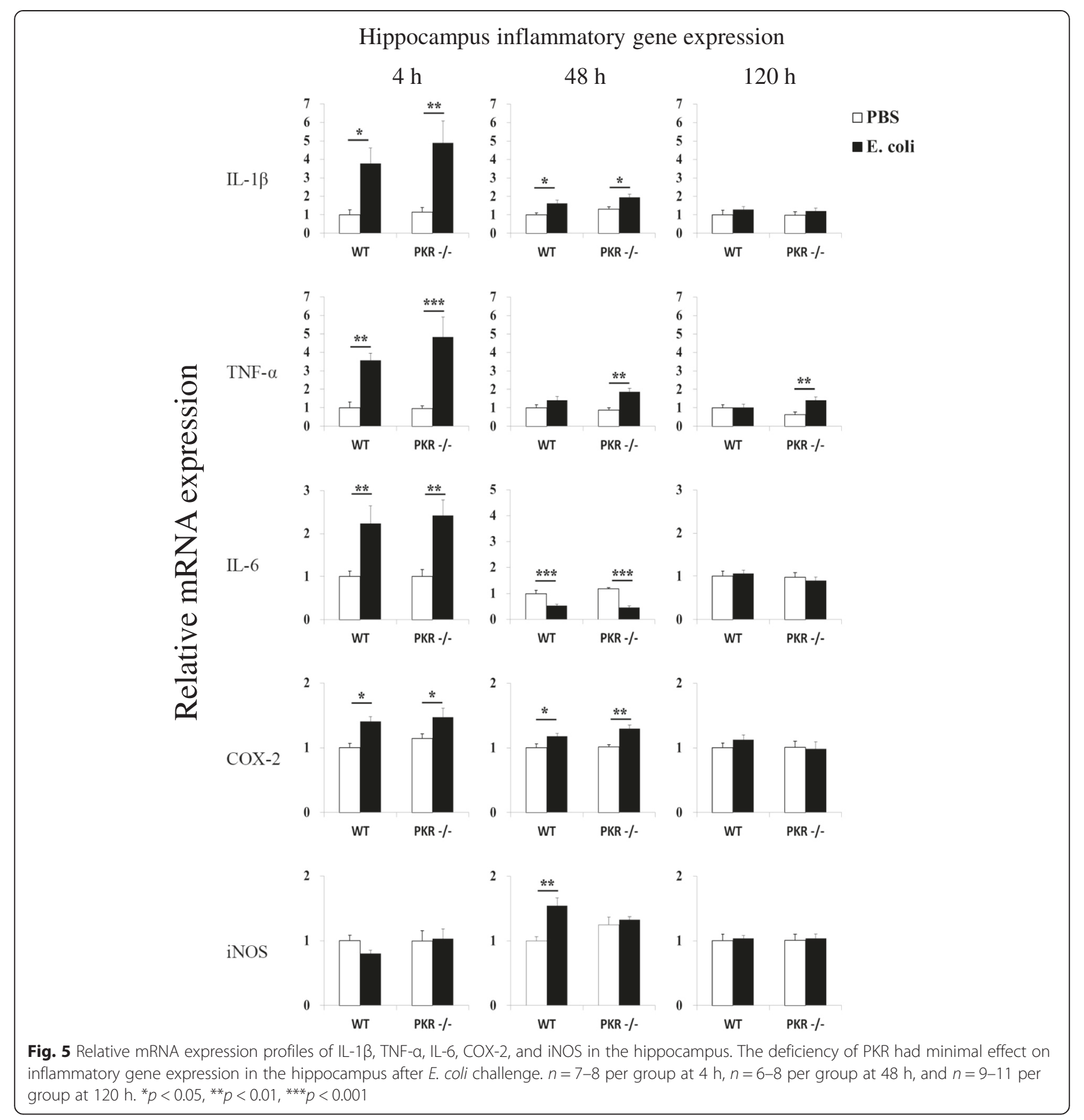

coli infection did not spread into the blood circulation in either genotype.

Consistent to the plate count results, the levels of bacterial $16 \mathrm{~S}$ rDNA in lavage fluid were also similar between WT and PKR-/- mice (Fig. 6b). Two-way ANOVA of the log transformed data indicated a main effect of time $(F=4.854$, df $2,75, p=0.01)$, but there was no interaction between time and genotype $(F=0.671$, df 2 , $75, p=0.542)$. Therefore, the change of $16 \mathrm{~S} \mathrm{rDNA}$ in lavage fluid across time points did not depend on the genotype. Since the level of $16 \mathrm{~S}$ rDNA was the highest at $48 \mathrm{~h}$, we also assessed the level of $16 \mathrm{~S}$ rDNA in blood at this time point (Fig. 6c). One-way ANOVA did not indicate any difference between the WT PBS, the WT E. coli, and the PKR E. coli experimental groups ( $F$ $=0.547$, df 2, 6, $p=0.605$ ). Hence, such data also implied that the bacterial infection did not spread into the blood in both genotypes. 


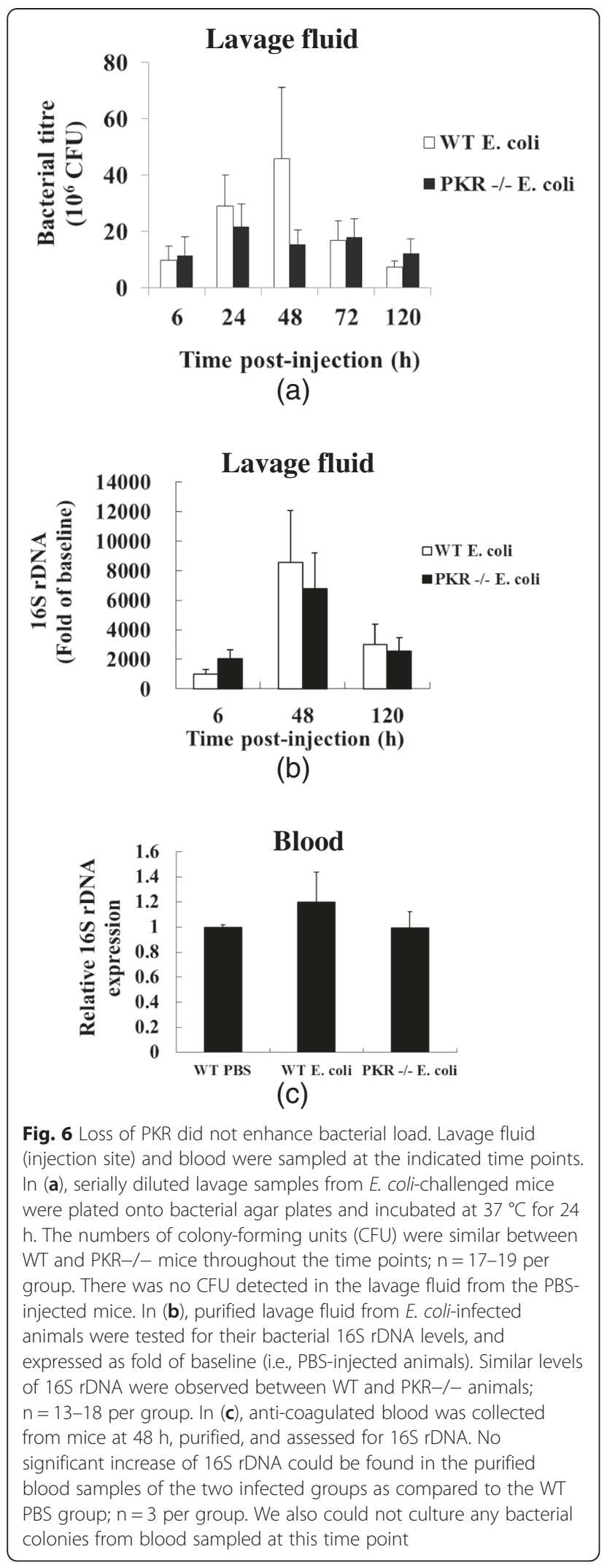

PKR-/- mice exhibited a delayed induction of CRH in the hypothalamus

It is known that systemic inflammation can trigger hypothalamic CRH production and release [77] and that endogenous $\mathrm{CRH}$ production mediates inflammationinduced sickness [58, 78]. As PKR-/- mice demonstrated several behavioral components of sickness that were not observed in WT mice, we asked whether the CRH response in PKR-/- mice would be different from that of WT mice.

We found that PKR-/- mice developed a delayed induction of $\mathrm{CRH}$ in the hypothalamus in response to $E$. coli challenge (Fig. 7a). At $4 \mathrm{~h}$ post-injection, $E$. coli significantly elevated CRH mRNA expression in WT mice ( $p=0.021$, one-way ANOVA followed by StudentNewman-Keuls post hoc comparison) but not in PKR-/mice ( $p=0.519)$, and a significant difference $(p=0.01)$ was also present between the $E$. coli-treated groups. In contrast, at 48 h post-injection, $E$. coli increased CRH expression only in PKR $-/-$ mice $(p=0.003)$ but not in WT mice $(p=0.851)$. Furthermore, the PKR $-/-E$. coli group showed a significantly greater expression of $\mathrm{CRH}$ $(p=0.003)$ than the WT E. coli group. Finally, no detectable differences $(p>0.05)$ in CRH expression could be observed at $120 \mathrm{~h}$.

\section{WT and PKR-/- mice showed similar changes in plasma corticosterone levels}

We then asked whether PKR-/- mice would display a different profile for circulating corticosterone than WT mice in response to $E$. coli. In rodents, basal plasma corticosterone levels follow a circadian pattern, with low levels occurring during the morning and high levels in the evening [79]. This circadian pattern can be observed in WT and PKR-/- mice, with corticosterone levels being higher (two-tailed tests, $p<0.01$ ) in the late afternoon $(4 \mathrm{~h} / 16: 00)$ than in the morning (i.e., $48 \mathrm{~h} / 12: 00)$, i.e., $4 \mathrm{~h}$ WT PBS $(363 \pm 42 \mathrm{ng} / \mathrm{ml})$ v.s. $48 \mathrm{~h} \mathrm{WT} \mathrm{PBS}(128 \pm 17 \mathrm{ng} /$ $\mathrm{ml}) ; 4$ h PKR-/- PBS (402 $\pm 50 \mathrm{ng} / \mathrm{ml})$ v.s. 48 h PKR-/PBS $(113 \pm 33 \mathrm{ng} / \mathrm{ml})$. Baseline corticosteroid levels did not differ between WT and PKR-/- mice (Fig. 7b). Oneway ANOVA followed by Student-Newman-Keuls post hoc comparison showed no difference $(p>0.05)$ between the WT PBS and PKR-/- PBS groups at either time point. Immune challenge by $E$. coli led to similar changes in plasma corticosterone levels in both genotypes. At $4 \mathrm{~h}, E$. coli increased corticosterone in both WT (WT PBS v.s. WT E. coli; $363 \pm 42$ v.s. $545 \pm 35 \mathrm{ng} / \mathrm{ml} ; p=0.023)$ and PKR-/- mice (PKR-/- PBS v.s. PKR-/- E. coli; $402 \pm 50$ v.s. $622 \pm 45 \mathrm{ng} / \mathrm{ml} ; p=0.004)$, but no difference was found between the E. coli-challenged groups (WT E. coli v.s. PKR-/ E. coli; $p=0.238$ ). By $48 \mathrm{~h}$, these increases had dissipated (WT PBS v.s. WT E. coli: $128 \pm 17$ v.s. $107 \pm 10$ pg/ml; PKR-/- PBS v.s. PKR-/- E. coli: $113 \pm 33$ 


\section{Hypothalamus}

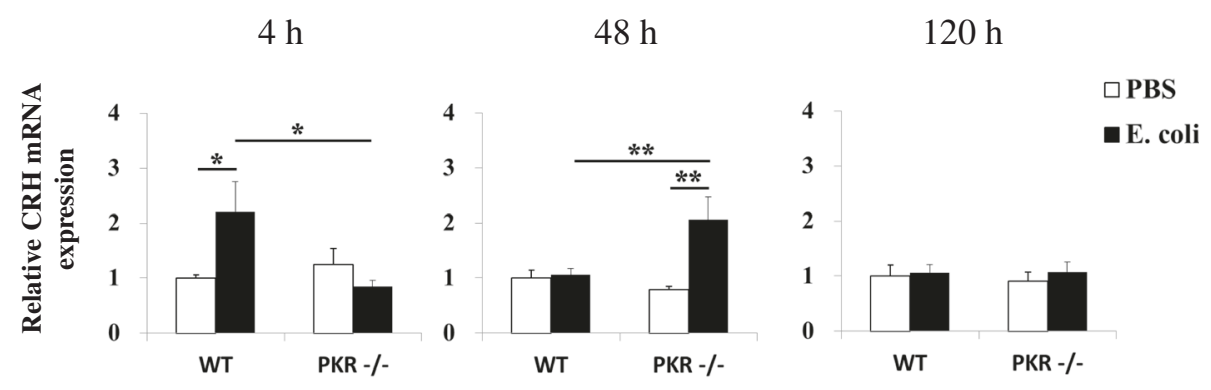

(a)

Plasma

$4 \mathrm{~h}$

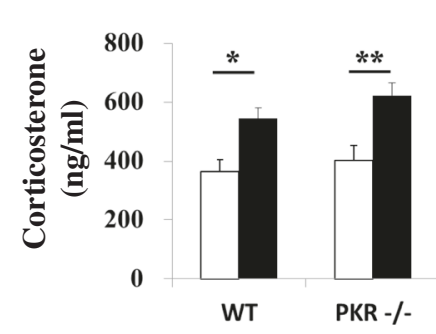

$48 \mathrm{~h}$

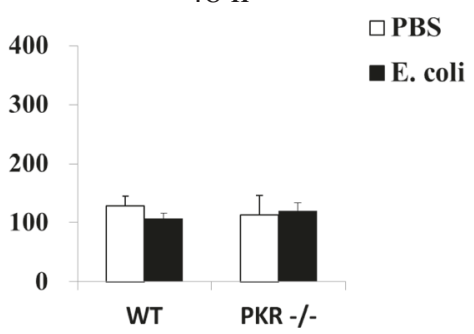

(b)

Fig. 7 PKR deficiency delayed hypothalamic CRH induction but did not affect the plasma corticosterone response. Hypothalamic CRH mRNA expression (a) and plasma corticosterone levels (b) were assessed at indicated times after $E$. coli challenge. As shown in $\mathbf{a}$, genetic deletion of PKR abolished the elevation of CRH by E. coli at $4 \mathrm{~h}$ but triggered a delayed increase in the PKR-/- E. coli group at $48 \mathrm{~h} . n=7-8$ per group at $4 \mathrm{~h}$, $n=6-8$ per group at $48 \mathrm{~h}$, and $n=9-11$ per group at $120 \mathrm{~h}$. ${ }^{*} p<0.05,{ }^{*} p<0.01$. In $\mathbf{b}$, E. coli caused similar increases of plasma corticosterone at $4 \mathrm{~h}$ (16:00) in WT and PKR-/- mice. By $48 \mathrm{~h}$ (12:00), corticosterone levels in the E. coli-treated groups had returned to control levels. $n=7-10$ per group at $4 h, n=5-7$ per group at $48 h ;{ }^{*} p<0.05,{ }^{* *} p<0.01$

v.s. $121 \pm 13 \mathrm{ng} / \mathrm{ml})$, and no significant difference $(p>0.05)$ could be detected between the experimental groups.

\section{Discussion}

Systemic inflammation triggers neuroimmune activation, leading to sickness. In this study, we investigated the role of PKR, a serine-threonine kinase that is activated by immune challenge $[45,46]$ and regulates LPS-induced peripheral inflammatory responses [48], on neuroimmune responses and sickness following subcutaneous E. coli infection. While genetic deficiency of PKR in mice did not affect the core components of sickness (anorexia and motor impairments), it led to several behavioral components of sickness (decreased burrowing, exploratory deficits, and social withdrawal) that were not observed in WT mice (Fig. 1). Interestingly, such alteration in the behavioral components was not due to exacerbated inflammation, since the loss of PKR diminished peripheral inflammatory changes (Figs. 2 and 3), and it had minimal effect on the associated neuroimmune responses (Figs. 4 and 5). Likewise, bacterial titers (Fig. 6) and plasma corticosterone profiles (Fig. 7b) did not differ between WT and PKR-/mice during the course of infection. Hence, the altered behavioral components in PKR-/- mice also did not result from an impaired host defense to the $E$. coli infection or from a dysregulated corticosterone response. However, PKR-/- mice displayed a delayed induction of CRH after E. coli challenge (Fig. 7), suggesting a postponed CRH response in these mice that may possibly modulate sickness.

As expected, genetic deletion of PKR suppressed peripheral inflammatory responses to $E$. coli infection. Previous studies have demonstrated that deficiency of PKR attenuates plasma IL-6 and IL-12 increases after systemic LPS challenge [48] and that PKR regulates inflammasome activation [51] and TLR2/TLR4-dependent cytokine release [46] from cultured macrophages. Moreover, PKR shows crosstalk with multiple inflammatory pathways including NF- $\mathrm{B}$ [47, 49], MAPK [48], IRF-1 [49], and JNK signaling cascades [46, 47]. Our findings are therefore in agreement with these earlier reports. Since systemic inflammatory mediators can communicate with the brain by neural and humoral routes to trigger 
neuroimmune activation $[3,19]$, we asked whether PKR deficiency could also suppress neuroimmune responses after $E$. coli challenge.

To our surprise, WT and PKR-/- mice displayed mostly similar neuroimmune changes. This is in contrast to several earlier studies, which showed that pharmacological inhibitors of PKR can abolish inflammatory responses in glial cultures [50,52, 80]. Until recently, it has also been demonstrated that genetic deletion or pharmacological inhibition of PKR reduces neuroinflammation in animal models of viral encephalomyelitis [53] and excitotoxic injury [54]. It should be noted that in these studies, inflammatory changes were initiated directly in glial cultures or by direct brain insults, whereas in our scenario neuroimmune activation occurred subsequently to subcutaneous inflammation caused by E. coli. This notable deviation suggests that PKR in the brain and PKR at peripheral tissues may act differentially to affect neuroimmune responses under different causes. It is known that systemic immune challenge can promote the recruitment of neutrophils [81-84] and monocytes $[85,86]$ into the brain and that infiltrating leukocytes can influence inflammatory changes in the brain $[84,87,88]$ and even LPS-induced depression-like behavior [84]. For instance, a single injection of LPS dose dependently elevates the number of infiltrating neutrophils into the facial nucleus within $48 \mathrm{~h}$, a phenomenon that can persist up to at least $96 \mathrm{~h}$ [83]. Given that $E$. coli challenge led to a sustained infection along with increased inflammatory factors up to $120 \mathrm{~h}$, it is expected to have a similar effect as a high dose of LPS to cause considerable leukocyte infiltration into the brain. One possibility could be that PKR may modulate this leukocyte infiltration process. Should this be the case, even if deficiency of PKR can downregulate the neuroimmune changes mediated by glial cells, this effect may be masked by the inflammatory responses elicited by the infiltrating leukocytes. Indeed, PKR-/- mice display enhanced $\mathrm{T}$ cell recruitment into the brain during viral encephalomyelitis [53], suggesting that PKR may also regulate the entry of other leukocyte cell types into the brain. Further investigation along this direction may provide clues as to how PKR controls neuroimmune activation during systemic immune insults.

Irrespective to the cause for the similar neuroimmune responses, PKR-/- mice did show decreased peripheral inflammatory changes. This finding led us to predict that sickness might also be diminished in PKR-/- mice, since sickness can be ameliorated by blockade of peripheral cytokine synthesis or their effects [27, 29, 32, 89], or by genetic deletion of NF- $\mathrm{kB}$ [90]. Therefore, we monitored both core (anorexia, motor impairments) and behavioral (burrowing and exploratory deficits, social withdrawal) components of sickness $[1,5,19,71,91]$ in WT and PKR-/- mice after E. coli challenge. Previous literature has shown that these two types of sickness components can be temporally [11, 92-94] and pharmacologically $[27,29,93,94]$ dissociated, indicating that the two types of sickness components involve different regulatory mechanisms. For example, LPS-induced deficit in burrowing can persist up to $24 \mathrm{~h}$, when the decrease in locomotor activity is no longer observed [11]. On the other hand, while administration of cyclooxygenase (COX) inhibitors can ameliorate both core (hypothermia, impaired locomotor activity) and behavioral (decreased burrowing) components of sickness following LPS challenge, blockade of peripheral cytokine synthesis by dexamethasone or dexamethasone-21-phosphate only attenuates LPSmediated hypothermia [27, 29]. Here, our data demonstrate a rather unexpected finding. Knockout of PKR in mice did not elicit any reduction in sickness responses. Instead, the core components of sickness were similar between both strains of mice, and the behavioral components of sickness were only observable in PKR-/- mice. Of particular interest is that PKR-/- mice showed decreased activities in the open field test, object investigation test, and social interaction test even at $120 \mathrm{~h}$, although these changes were absent in WT mice at the same time point. It should be noted that these exploratory and social deficits observed only in PKR-/- mice were not simply because of a general decrease in motor activity, because rotarod performance had been restored to the control level by $96 \mathrm{~h}$. Thus, this is an indication that deficiency of PKR primarily affected the behavioral components of sickness but not the core components. We did not perform these tasks at an earlier time because we had specifically wanted to distinguish the roles of PKR on the core and behavioral components of sickness. Moreover, both strains of mice displayed decreased rotarod performance at $24 \mathrm{~h}$, indicating that the use of these behavioral assays at or before this time would not allow us to separate the effects of the core and behavioral components of sickness. Given that LPS is well reported to abolish exploratory activity $[10,95]$ and induce social withdrawal [96-98] in WT animals within several hours after systemic administration, it is likely that $E$. coli can also lead to these deficits in the two strains of mice under this time frame.

Interestingly, we did not detect any change in the burrowing activity of WT mice after E. coli. This would seem contradictory to earlier reports which demonstrated that LPS acutely decreases burrowing in WT animals $[11,27,28]$. However, it should be emphasized that these studies have used food pellets as the burrowing substrate, whereas here we used bedding material (wood chips) to avoid interference effects on the measurements of food consumption. It has been documented that different types of burrowing substrates can greatly influence the burrowing activity measured in rodents $[99,100]$. C57BL/ 6 mice typically burrow a greater proportion of the 
burrowing substrate when the burrowing tube is filled with bedding material than when it is filled with food pellets. For example, Kir6.2 knockout mice display severely impaired burrowing as compared to WT mice when food pellets are used, but this difference becomes less obvious when the burrowing substrate is replaced with bedding material [99]. Based on these studies, it could be deduced that bedding material is more preferred than food pellets as a burrowing substrate by C57BL/6 mice, such that it will be harder to detect phenotypic differences with bedding material than with food pellets. Perhaps WT mice would have displayed burrowing deficits after $E$. coli challenge if the burrowing tubes had been filled with food pellets.

Next, we asked whether the alterations in the behavioral components of sickness of PKR-/- mice would be correlated with exaggerated bacterial load. It has been well reported that loss of PKR can often enhance viral replication [41, 44, 101, 102]. Another study has shown that PKR is involved in resistance to Toxoplasma gondii [45]. To our knowledge, however, the effect of PKR in bacterial infection has been little investigated [51]. Here, we made use of two different methods, i.e., microbiological plate count and quantification of $16 \mathrm{~S}$ rDNA by real-time PCR, and show that bacterial titers were similar between the two strains of mice throughout the course of infection. These results imply that altered sickness in PKR $-/-$ mice was not due to an impaired host defense to E. coli. In fact, even if PKR deficiency does affect $E$. coli infection, it would likely suppress it. This point is supported by another study by $\mathrm{Lu}$ et al., in which PKR-/- mice had reduced bacterial titers following E. coli-induced peritonitis [51].

We then investigated if PKR could modulate the CRH response to E. coli challenge. Previous studies have indicated that systemic inflammation leads to $\mathrm{CRH}$ induction and release from paraventricular nucleus (PVN) neurons of the hypothalamus [56, 77]. Furthermore, administration of $\mathrm{CRH}$ into rodents acutely reduces exploratory activities to novel environments [103] and to novel individuals [104]. These behaviors are quite similar to what was observed in PKR-/- mice at $120 \mathrm{~h}$ after $E$. coli challenge. Our data indicate that while E. coli upregulated $\mathrm{CRH}$ expression at $4 \mathrm{~h}$ in the hypothalamus of WT mice, such increase was not found in PKR-/- mice. This finding is not surprising, given that systemic inflammation induces CRH, and PKR-/- mice showed reduced peripheral inflammation. However, at $48 \mathrm{~h}$ after $E$. coli infection, there was a significant elevation of $\mathrm{CRH}$ in PKR-/- mice but not in WT mice. Hence, it appears that PKR deficiency can delay CRH induction in response to E. coli. It is also possible that knockout of PKR may extend the CRH response period, although this requires validation in a more detailed temporal manner.
The altered CRH response in PKR-/- mice suggest that these CRH-mediated effects may also be postponed or extended, which can possibly alter the behavioral components of sickness in PKR-/- mice. Indeed, chronic administration of $\mathrm{CRH}$ into the brain can delay behavioral inhibition induced by LPS [105], thus providing indirect evidence to support this possibility. Future studies should address the role of PKR on the CRH response along with its implication on sickness.

We have known that CRH participates in the HPA axis to stimulate adrenocorticotrophic hormone (ACTH) synthesis and release from the anterior pituitary [77]. ACTH in turn acts on the adrenal cortex, inducing corticosterone production and secretion. Upon systemic LPS challenge, corticosterone is increased in the circulation, and several reports have also demonstrated that endogenous corticosterone can suppress peripheral inflammation and sickness $[55,59,60]$. As PKR-/- mice exhibited a delayed $\mathrm{CRH}$ induction, we questioned whether this would result in differential responses of corticosterone to E. coli. Surprisingly, there was no significant change in the levels of plasma corticosterone between WT and PKR-/- mice. Plasma corticosterone levels were elevated by E. coli to the same extent in WT and PKR-/- mice at $4 \mathrm{~h}$, and by $48 \mathrm{~h}$ these increases had disappeared in the E. coli-challenged groups. These results suggest that the altered sickness behaviors in PKR-/- mice were not due to a dysregulated corticosterone response. Furthermore, corticosterone profiles in the two strains of mice did not follow the same trend as that of hypothalamic CRH. While CRH induction was blunted at $4 \mathrm{~h}$ in PKR-/- mice relative to WT mice, corticosterone was similarly increased in both genotypes. At $48 \mathrm{~h}, \mathrm{CRH}$ was induced in PKR-/- mice, but plasma corticosterone was not upregulated. Such a discrepancy between the $\mathrm{CRH}$ and corticosterone profiles might be due to the following possibilities. Firstly, CRH production is not limited to the hypothalamus. Extra-hypothalamic sources of CRH [106-109] may likely serve as alternative source(s) of CRH in PKR-/- mice, such that hypothalamic $\mathrm{CRH}$ production would not be required at $4 \mathrm{~h}$ in these mice. Of particular relevance is that $\mathrm{CRH}$ is highly expressed at peripheral inflammatory tissues to regulate local immune responses [109]. If deficiency of PKR can hyper-induce $\mathrm{CRH}$ at inflammatory sites during the $E$. coli infection, such CRH may potentially spill over into the bloodstream and upregulate corticosterone. Secondly, while corticosterone production is regulated by $\mathrm{CRH}$, it can also be triggered by vasopressin through the type $1 \mathrm{~b}$ vasopressin receptor in the anterior pituitary [110]. Perhaps PKR can act at the level of vasopressin system, thereby exerting its control over the level of corticosterone. Thirdly, elevated corticosterone has been shown to decrease CRH-R1 mRNA and CRH binding [111]. Since corticosterone was increased before $48 \mathrm{~h}$ in PKR-/- 
mice, this could explain why these mice were unable to mount another wave of corticosterone response even though CRH was induced at $48 \mathrm{~h}$.

It is noteworthy that despite the dissociation between hypothalamic $\mathrm{CRH}$ and circulating corticosterone profiles in PKR-/- mice, the possible involvement of the delayed $\mathrm{CRH}$ response in altering sickness behaviors should not be simply ruled out. CRH participates in the HPA axis, but $\mathrm{CRH}$ effects are not entirely mediated by ACTH or corticosterone. $\mathrm{CRH}$ is a neurotransmitter and it can bind to widely distributed receptors CRH-R1 and CRH-R2 in the brain [112]. Indeed, many of the brain regions that express $\mathrm{CRH}$ receptors, including the hippocampus, amygdala, hypothalamus, midbrain, and cerebral cortex, are not responsible for $\mathrm{ACTH}$ production. Instead, direct manipulation of $\mathrm{CRH}$ signaling in these brain structures often results in behavioral changes that are also observed in sickness. For instance, specific deletion of CRH-R1 in midbrain dopaminergic neurons causes anxiety and inhibits dopamine release in the prefrontal cortex [113]. In the same study, it was shown that deletion of CRH-R1 in forebrain glutamatergic neurons decreases anxiety and neurotransmission in the hippocampus and amygdala. Moreover, the direct infusion of CRH into the hippocampus enhances long-term potentiation and improves context-dependent fear conditioning [114]. Interestingly, many of the brain structures that express CRH receptors are also involved in sickness [20], thus supporting for a role of $\mathrm{CRH}$ in modulating sickness. A delay in the CRH response in PKR-/- mice suggests that endogenous $\mathrm{CRH}$ signaling at an early time after the $E$. coli infection is required for normal sickness development.

In addition to the delayed CRH response, other parameters can be studied in future to better understand sickness in PKR-/- mice. For example, many inflammatory mediators such as NF- $\mathrm{kB}$ [90], microsomal PGE synthase-1 (mPGES-1) $[115,116]$, and transcription factor nuclear factor interleukin 6 (NF-IL-6) [117] have been demonstrated to control sickness and are potential candidates to alter sickness behaviors in PKR-/- mice. In particular, PKR modulates NF- $\mathrm{KB}$ activation [47, 49], and genetic deletion of NF- $\mathrm{kB}$ abolishes sickness induced by LPS and unmethylated cytosine-phosphateguanosine motifs (CpG-DNA) [90]. We have focused on quantifying inflammatory gene expression in the brain. This was because inflammatory gene expression serves as a good indicator of local neuroimmune activation and that it could enable us to assess multiple inflammatory markers with a limited amount of sample material. Subsequent investigation of neuroimmune markers at protein level would be important to further characterize neuroimmune responses and their relationships to sickness. For example, iNOS mRNA expression was increased to a slightly lesser degree in the PKR $-/-E$. coli group than in the WT E. coli group at $48 \mathrm{~h}$ in the hypothalamus. It is known that systemic LPS upregulates iNOS mRNA expression in the hypothalamus [118] and that pharmacological inhibition of iNOS attenuates LPSinduced sickness responses [34]. Our mRNA results raise questions as to whether $E$. coli could indeed upregulate iNOS protein in the hypothalamus and if PKR could modulate iNOS protein production that can potentially affect sickness. Finally, systemic inflammation can activate the indoleamine-2,3-dioxygenase (IDO) pathway, leading to the catabolism of tryptophan (TRP) to kynurenine (KYN) in the brain and blood [94]. In the same study, pharmacological inhibition of the IDO pathway was shown to alleviate LPS-induced depressive-like behavior. In another study, genetic deletion or pharmacological inhibition of IDO ameliorates depressive-like behaviors triggered by an intracerebroventricular injection of LPS [119]. Since PKR-/- mice developed exploratory activity and social interaction deficits up to $120 \mathrm{~h}$, a dysregulation of the IDO pathway is another reasonable possibility that may account for these altered sickness behaviors.

A major limitation of our study is that we have used a general knockout approach to model the effect of PKR on neuroimmune activation and sickness. Since PKR is ubiquitously expressed, it is difficult to pinpoint tissuespecific effects of PKR during systemic inflammation. For instance, we discussed the possibility that PKR deletion at peripheral tissues may enhance leukocyte recruitment into the brain, thereby masking the reduction of neuroimmune responses in glial cells. This issue can be more easily studied if PKR conditional knockout mice were used. Perhaps, it will be beneficial to generate different lines of mice having specific knockout of PKR in target tissues, so as to better characterize the role of PKR during systemic inflammation.

We believe that our findings have important implications. Firstly, we identify a novel role of PKR in regulating sickness, particularly the behavioral components of sickness. As an over-exaggeration of sickness may precipitate depression $[5,19]$ and/or delirium $[3,6]$, gaining a better understanding on sickness regulation can shed light on how to fine tune sickness responses. Ideally, one would want to preserve the physiological functions of sickness without causing severe side effects. Secondly, reports in the recent decade have demonstrated that PKR inhibition can be neuroprotective [119-122] and improve cognition [123]. Here, we provide additional information on PKR deficiency during systemic inflammation, and this can complement the earlier studies. While we did show that loss of PKR altered the behavioral components of sickness, we should not simply neglect the desirable effects of PKR inhibition in neurodegenerative processes and memory. Instead, the efficacy of PKR 
pharmacological inhibitors should be justified after considering both positive and negative effects and taking into account of the patient's disease status.

\section{Conclusions}

Systemic inflammation leads to neuroimmune activation and sickness. While these phenomena have been well studied, the mechanisms involved in their regulation remain unclear. Our study indicates that genetic deletion of PKR led to alteration in the behavioral components of sickness and this was unlikely to be caused by exaggerated neuroimmune responses, increased bacterial load, or a dysregulated corticosterone response. Instead, PKR deficiency delayed $\mathrm{CRH}$ induction after immune challenge by $E$. coli. Future investigations can address the role of PKR in the CRH response, together with its relation to sickness.

\section{Competing interests}

The authors declare that they have no competing interests.

\section{Authors' contributions}

DP designed and performed experiments, analyzed data, and wrote the manuscript. RY and HT participated in the behavioral experiments and data analysis. $\mathrm{YH}$ and $\mathrm{KC}$ designed the experiments. $\mathrm{RC}$ was in charge of the project, designed the experiments, and wrote the manuscript. All authors read and approved the final manuscript.

\section{Acknowledgements}

This study is supported by University of Hong Kong (HKU) Seed Funding for Incubating Group-based Collaborative Research Project, HKU Seed Funding for Basic Research (201311159171), HKU Alzheimer's Disease Research Network under Strategic Research Theme on Ageing, and generous donation from Ms. Kit-Wan Chow.

\section{Author details \\ ${ }^{1}$ Laboratory of Neurodegenerative Diseases, School of Biomedical Sciences, LKS Faculty of Medicine, The University of Hong Kong, Hong Kong SAR, China. ${ }^{2}$ Research Centre of Heart, Brain, Hormone and Healthy Aging, LKS Faculty of Medicine, The University of Hong Kong, Hong Kong SAR, China. ${ }^{3}$ State Key Laboratory of Brain and Cognitive Sciences, The University of Hong Kong, Hong Kong SAR, China. ${ }^{4}$ School of Nursing, Faculty of Health and Social Sciences, The Hong Kong Polytechnic University, Hung Hom, Kowloon, Hong Kong SAR, China. ${ }^{5}$ Department of Ophthalmology, LKS Faculty of Medicine, The University of Hong Kong, Hong Kong SAR, China. ${ }^{6}$ Rm. L1-49, Laboratory Block, Faculty of Medicine Building, 21 Sassoon Road, Pokfulam, Hong Kong SAR, China.}

Received: 28 May 2015 Accepted: 14 November 2015 Published online: 19 November 2015

\section{References}

1. Dantzer R. Cytokine, sickness behavior, and depression. Immunol Allergy Clin North Am. 2009;29:247-64.

2. Dantzer R. Cytokine-induced sickness behavior: where do we stand? Brain Behav Immun. 2001;15:7-24.

3. Poon DC, Ho YS, Chiu K, Chang RC. Cytokines: how important are they in mediating sickness? Neurosci Biobehav Rev. 2013;37:1-10.

4. Hart BL. Biological basis of the behavior of sick animals. Neurosci Biobehav Rev. 1988;12:123-37.

5. Maes M, Berk M, Goehler L, Song C, Anderson G, Galecki P, et al. Depression and sickness behavior are Janus-faced responses to shared inflammatory pathways. BMC Med. 2012;10:66.

6. Cunningham C, Maclullich AM. At the extreme end of the psychoneuroimmunological spectrum: delirium as a maladaptive sickness behaviour response. Brain Behav Immun. 2012;28:1-13.
7. Suehiro E, Fujisawa $H$, Ito H, Ishikawa T, Maekawa T. Brain temperature modifies glutamate neurotoxicity in vivo. J Neurotrauma. 1999;16:285-97.

8. Mogensen TH. Pathogen recognition and inflammatory signaling in innate immune defenses. Clin Microbiol Rev. 2009;22:240-73. Table of Contents.

9. Bianchi ME. DAMPs, PAMPs and alarmins: all we need to know about danger. J Leukoc Biol. 2007;2007(81):1-5.

10. Skelly DT, Hennessy E, Dansereau MA, Cunningham C. A systematic analysis of the peripheral and CNS effects of systemic LPS, IL-1Beta, TNF-alpha and IL-6 challenges in C57BL/6 mice. PLoS One. 2013;8, e69123.

11. Cunningham C, Campion S, Lunnon K, Murray CL, Woods JF, Deacon RM, et al. Systemic inflammation induces acute behavioral and cognitive changes and accelerates neurodegenerative disease. Biol Psychiatry. 2009;65:304-12.

12. Li Z, Perlik V, Feleder C, Tang Y, Blatteis CM. Kupffer cell-generated PGE2 triggers the febrile response of guinea pigs to intravenously injected LPS. Am J Physiol Regul Integr Comp Physiol. 2006;290:R1262-1270.

13. Griffin EW, Skelly DT, Murray CL, Cunningham C. Cyclooxygenase-1dependent prostaglandins mediate susceptibility to systemic inflammationinduced acute cognitive dysfunction. J Neurosci. 2013;33:15248-58.

14. Perlik V, Li Z, Goorha S, Ballou LR, Blatteis CM. LPS-activated complement, not LPS per se, triggers the early release of PGE2 by Kupffer cells. Am J Physiol Regul Integr Comp Physiol. 2005;289:R332-9.

15. Blatteis CM, Li S, Li Z, Perlik V, Feleder C. Signaling the brain in systemic inflammation: the role of complement. Front Biosci. 2004;9:915-31.

16. Blatteis CM. The onset of fever: new insights into its mechanism. Prog Brain Res. 2007;162:3-14.

17. Konsman JP, Luheshi GN, Bluthe RM, Dantzer R. The vagus nerve mediates behavioural depression, but not fever, in response to peripheral immune signals; a functional anatomical analysis. Eur J Neurosci. 2000;12:4434-46.

18. Banks WA, Ortiz L, Plotkin SR, Kastin AJ. Human interleukin (IL) 1 alpha, murine IL-1 alpha and murine IL-1 beta are transported from blood to brain in the mouse by a shared saturable mechanism. J Pharmacol Exp Ther. 1991;259:988-96.

19. Dantzer R, O'Connor JC, Freund GG, Johnson RW, Kelley KW. From inflammation to sickness and depression: when the immune system subjugates the brain. Nat Rev Neurosci. 2008;9:46-56.

20. Poon DC, Ho YS, Chiu K, Wong HL, Chang RC. Sickness: from the focus on cytokines, prostaglandins, and complement factors to the perspectives of neurons. Neurosci Biobehav Rev. 2015;57:30-45.

21. Stefferl A, Hopkins SJ, Rothwell NJ, Luheshi GN. The role of TNF-alpha in fever: opposing actions of human and murine TNF-alpha and interactions with IL-beta in the rat. Br J Pharmacol. 1996;118:1919-24.

22. Morimoto A, Long NC, Nakamori T, Murakami N. The effect of prostaglandin E2 on the body temperature of restrained rats. Physiol Behav. 1991;50:249-53.

23. Palin K, Bluthe RM, McCusker RH, Levade T, Moos F, Dantzer R, et al. The type 1 TNF receptor and its associated adapter protein, FAN, are required for TNFalpha-induced sickness behavior. Psychopharmacology. 2009;201:549-56.

24. Kent S, Bluthe RM, Dantzer R, Hardwick AJ, Kelley KW, Rothwell NJ, et al. Different receptor mechanisms mediate the pyrogenic and behavioral effects of interleukin 1. Proc Natl Acad Sci U S A. 1992;89:9117-20.

25. Harden LM, du Plessis I, Poole S, Laburn HP. Interleukin (IL)-6 and IL-1 beta act synergistically within the brain to induce sickness behavior and fever in rats. Brain Behav Immun. 2008;22:838-49.

26. Scammell TE, Elmquist JK, Griffin JD, Saper CB. Ventromedial preoptic prostaglandin E2 activates fever-producing autonomic pathways. J Neurosci. 1996:16:6246-54.

27. Teeling $J$, Cunningham $C$, Newman TA, Perry VH. The effect of nonsteroidal anti-inflammatory agents on behavioural changes and cytokine production following systemic inflammation: implications for a role of COX-1. Brain Behav Immun. 2010;24:409-19.

28. Teeling JL, Felton LM, Deacon RM, Cunningham C, Rawlins JN, Perry VH. Sub-pyrogenic systemic inflammation impacts on brain and behavior, independent of cytokines. Brain Behav Immun. 2007;21:836-50.

29. Murray CL, Skelly DT, Cunningham C. Exacerbation of CNS inflammation and neurodegeneration by systemic LPS treatment is independent of circulating IL-1beta and IL-6. J Neuroinflammation. 2011;8:50.

30. Sehic $E_{\text {, }} \mathrm{Li}$ S, Ungar AL, Blatteis $\mathrm{CM}$. Complement reduction impairs the febrile response of guinea pigs to endotoxin. Am J Physiol. 1998;274:R1594-1603. 
31. Li S, Boackle SA, Holers VM, Lambris JD, Blatteis CM. Complement component $\mathrm{c} 5 \mathrm{a}$ is integral to the febrile response of mice to lipopolysaccharide. Neuroimmunomodulation. 2005;12:67-80

32. Bluthe RM, Dantzer R, Kelley KW. Effects of interleukin-1 receptor antagonist on the behavioral effects of lipopolysaccharide in rat. Brain Res. 1992:573:318-20.

33. Harden LM, du Plessis I, Poole S, Laburn HP. Interleukin-6 and leptin mediate lipopolysaccharide-induced fever and sickness behavior. Physiol Behav. 2006:89:146-55

34. Riediger T, Cordani C, Potes CS, Lutz TA. Involvement of nitric oxide in lipopolysaccharide induced anorexia. Pharmacol Biochem Behav. 2010;97:112-20.

35. Williams BR. Signal integration via PKR. Sci STKE. 2001;2001:re2.

36. Kang R, Tang D. PKR-dependent inflammatory signals. Sci Signal. 2012;5:pe47

37. Garcia MA, Meurs EF, Esteban M. The dsRNA protein kinase PKR: virus and cell control. Biochimie. 2007:89:799-811.

38. Nanduri S, Carpick BW, Yang Y, Williams BR, Qin J. Structure of the doublestranded RNA-binding domain of the protein kinase PKR reveals the molecular basis of its dsRNA-mediated activation. EMBO J. 1998;17:5458-65.

39. Li S, Peters GA, Ding K, Zhang X, Qin J, Sen GC. Molecular basis for PKR activation by PACT or dsRNA. Proc Natl Acad Sci U S A. 2006;103:10005-10.

40. Lee SB, Melkova Z, Yan W, Williams BR, Hovanessian AG, Esteban M. The interferon-induced double-stranded RNA-activated human p68 protein kinase potently inhibits protein synthesis in cultured cells. Virology. 1993;192:380-5.

41. Balachandran S, Roberts PC, Brown LE, Truong H, Pattnaik AK, Archer DR, et al. Essential role for the dsRNA-dependent protein kinase PKR in innate immunity to viral infection. Immunity. 2000;13:129-41.

42. Baltzis D, Qu LK, Papadopoulou S, Blais JD, Bell JC, Sonenberg N, et al. Resistance to vesicular stomatitis virus infection requires a functional cross talk between the eukaryotic translation initiation factor 2alpha kinases PERK and PKR. J Virol. 2004;78:12747-61.

43. Alirezaei M, Watry DD, Flynn CF, Kiosses WB, Masliah E, Williams BR, et al. Human immunodeficiency virus-1/surface glycoprotein 120 induces apoptosis through RNA-activated protein kinase signaling in neurons. J Neurosci. 2007;27:11047-55.

44. Barry G, Breakwell L, Fragkoudis R, Attarzadeh-Yazdi G, Rodriguez-Andres J, Kohl A, et al. PKR acts early in infection to suppress Semliki Forest virus production and strongly enhances the type I interferon response. J Gen Virol. 2009;90:1382-91.

45. Ogolla PS, Portillo JA, White CL, Patel K, Lamb B, Sen GC, et al. The protein kinase double-stranded RNA-dependent (PKR) enhances protection against disease cause by a non-viral pathogen. PLoS Pathog. 2013;9, e1003557.

46. Cabanski M, Steinmuller M, Marsh LM, Surdziel E, Seeger W, Lohmeyer J. PKR regulates TLR2/TLR4-dependent signaling in murine alveolar macrophages. Am J Respir Cell Mol Biol. 2008;38:26-31.

47. Takada Y, Ichikawa H, Pataer A, Swisher S, Aggarwal BB. Genetic deletion of PKR abrogates TNF-induced activation of IkappaBalpha kinase, JNK, Akt and cell proliferation but potentiates p44/p42 MAPK and p38 MAPK activation. Oncogene. 2007;26:1201-12.

48. Goh KC, de Veer MJ, Williams BR. The protein kinase PKR is required for p38 MAPK activation and the innate immune response to bacterial endotoxin. EMBO J. 2000;19:4292-7.

49. Kumar A, Yang YL, Flati V, Der S, Kadereit S, Deb A, et al. Deficient cytokine signaling in mouse embryo fibroblasts with a targeted deletion in the PKR gene: role of IRF-1 and NF-kappaB. EMBO J. 1997;16:406-16.

50. Lee JH, Park EJ, Kim OS, Kim HY, Joe EH, Jou I. Double-stranded RNA-activated protein kinase is required for the LPS-induced activation of STAT1 inflammatory signaling in rat brain glial cells. Glia. 2005;50:66-79.

51. Lu B, Nakamura T, Inouye K, Li J, Tang Y, Lundback P, et al. Novel role of PKR in inflammasome activation and HMGB1 release. Nature. 2012;488:670-4.

52. Couturier J, Paccalin M, Morel M, Terro F, Milin S, Pontcharraud R, et al. Prevention of the beta-amyloid peptide-induced inflammatory process by inhibition of double-stranded RNA-dependent protein kinase in primary murine mixed co-cultures. J Neuroinflammation. 2011;8:72.

53. Kapil P, Stohlman SA, Hinton DR, Bergmann CC. PKR mediated regulation of inflammation and IL-10 during viral encephalomyelitis. J Neuroimmunol. 2014:270:1-12.

54. Tronel C, Page G, Bodard S, Chalon S, Antier D. The specific PKR inhibitor C16 prevents apoptosis and IL-1beta production in an acute excitotoxic rat mode with a neuroinflammatory component. Neurochem Int. 2014;64:73-83.
55. Silverman MN, Mukhopadhyay P, Belyavskaya E, Tonelli LH, Revenis BD, Doran $\mathrm{JH}$, et al. Glucocorticoid receptor dimerization is required for proper recovery of LPS-induced inflammation, sickness behavior and metabolism in mice. Mol Psychiatry. 2013;18:1006-17.

56. Takemura T, Makino S, Takao T, Asaba K, Suemaru S, Hashimoto K. Hypothalamic-pituitary-adrenocortical responses to single vs. repeated endotoxin lipopolysaccharide administration in the rat. Brain Res. 1997;767:181-91.

57. Beishuizen A, Thijs LG. Endotoxin and the hypothalamo-pituitary-adrenal (HPA) axis. J Endotoxin Res. 2003;9:3-24.

58. Uehara A, Sekiya C, Takasugi Y, Namiki M, Arimura A. Anorexia induced by interleukin 1: involvement of corticotropin-releasing factor. Am J Physiol. 1989;257:R613-617.

59. Pezeshki G, Pohl T, Schobitz B. Corticosterone controls interleukin-1 beta expression and sickness behavior in the rat. J Neuroendocrinol. 1996;8:129-35

60. Johnson RW, Propes MJ, Shavit Y. Corticosterone modulates behavioral and metabolic effects of lipopolysaccharide. Am J Physiol. 1996;270:R192-198.

61. Yang YL, Reis LF, Pavlovic J, Aguzzi A, Schafer R, Kumar A, et al. Deficient signaling in mice devoid of double-stranded RNA-dependent protein kinase. EMBO J. 1995;14:6095-106.

62. Barrientos RM, Watkins LR, Rudy JW, Maier SF. Characterization of the sickness response in young and aging rats following E. coli infection. Brain Behav Immun. 2009;23:450-4

63. Barrientos RM, Higgins EA, Biedenkapp JC, Sprunger DB, Wright-Hardesty KJ, Watkins $L R$, et al. Peripheral infection and aging interact to impair hippocampal memory consolidation. Neurobiol Aging. 2006;27:723-32.

64. Campisi J, Hansen MK, O'Connor KA, Biedenkapp JC, Watkins LR, Maier SF, et al. Circulating cytokines and endotoxin are not necessary for the activation of the sickness or corticosterone response produced by peripheral E. coli challenge. J Appl Physiol. 2003;95:1873-82.

65. Curzon P, Zhang M, Radek RJ, Fox GB. The behavioral assessment of sensorimotor processes in the mouse: acoustic startle, sensory gating, locomotor activity, rotarod, and beam walking. In: Buccafusco JJ, editor. Methods of behavior analysis in neuroscience. 2nd ed. Boca Raton (FL): Frontiers in Neuroscience; 2009.

66. Walsh RN, Cummins RA. The open-field test: a critical review. Psychol Bull. 1976;83:482-504

67. Zhan Y, Paolicelli RC, Sforazzini F, Weinhard L, Bolasco G, Pagani F, et al. Deficient neuron-microglia signaling results in impaired functional brain connectivity and social behavior. Nat Neurosci. 2014;17:400-6.

68. Vaguliene N, Zemaitis M, Lavinskiene S, Miliauskas S, Sakalauskas R. Local and systemic neutrophilic inflammation in patients with lung cancer and chronic obstructive pulmonary disease. BMC Immunol. 2013;14:36.

69. Jordan JA, Durso MB. Real-time polymerase chain reaction for detecting bacterial DNA directly from blood of neonates being evaluated for sepsis. J Mol Diagn. 2005;7:575-81

70. Olsen $\mathrm{CH}$. Review of the use of statistics in infection and immunity. Infect Immun. 2003;71:6689-92.

71. Kelley KW, Bluthe RM, Dantzer R, Zhou JH, Shen WH, Johnson RW, et al. Cytokine-induced sickness behavior. Brain Behav Immun. 2003;17 Suppl 1:S112-118.

72. Stunden HJ, Latz E. PKR stirs up inflammasomes. Cell Res. 2013;23:168-70.

73. Armbrust T, Ramadori G. Functional characterization of two different Kupffer cell populations of normal rat liver. J Hepatol. 1996;25:518-28.

74. Bette M, Kaut O, Schafer MK, Weihe E. Constitutive expression of p55TNFR mRNA and mitogen-specific up-regulation of TNF alpha and p75TNFR mRNA in mouse brain. J Comp Neurol. 2003:465:417-30.

75. Cunningham Jr ET, Wada E, Carter DB, Tracey DE, Battey JF, De Souza EB. In situ histochemical localization of type I interleukin-1 receptor messenger RNA in the central nervous system, pituitary, and adrenal gland of the mouse. J Neurosci. 1992;12:1101-14.

76. Vitkovic L, Bockaert J, Jacque C. "Inflammatory" cytokines: neuromodulators in normal brain? J Neurochem. 2000;74:457-71.

77. Berkenbosch F, van Oers J, del Rey A, Tilders F, Besedovsky H. Corticotropinreleasing factor-producing neurons in the rat activated by interleukin-1. Science. 1987;238:524-6.

78. Milton NG, Hillhouse EW, Milton AS. A possible role for endogenous peripheral corticotrophin-releasing factor- 41 in the febrile response of conscious rabbits. J Physiol. 1993;465:415-25.

79. Malisch JL, Breuner CW, Gomes FR, Chappell MA, Garland Jr T. Circadian pattern of total and free corticosterone concentrations, corticosteroid-binding globulin, 
and physical activity in mice selectively bred for high voluntary wheel-running behavior. Gen Comp Endocrinol. 2008;156:210-7.

80. Auch CJ, Saha RN, Sheikh FG, Liu X, Jacobs BL, Pahan K. Role of protein kinase $R$ in double-stranded RNA-induced expression of nitric oxide synthase in human astroglia. FEBS Lett. 2004;563:223-8.

81. Zhou H, Andonegui G, Wong CH, Kubes P. Role of endothelial TLR4 for neutrophil recruitment into central nervous system microvessels in systemic inflammation. J Immunol. 2009:183:5244-50.

82. Rummel C, Inoue W, Poole S, Luheshi GN. Leptin regulates leukocyte recruitment into the brain following systemic LPS-induced inflammation. Mol Psychiatry. 2010;15:523-34.

83. Bohatschek M, Werner A, Raivich G. Systemic LPS injection leads to granulocyte influx into normal and injured brain: effects of ICAM-1 deficiency. Exp Neurol. 2001;172:137-52.

84. Aguilar-Valles A, Kim J, Jung S, Woodside B, Luheshi GN. Role of brain transmigrating neutrophils in depression-like behavior during systemic infection. Mol Psychiatry. 2014;19:599-606.

85. Drevets DA, Schawang JE, Dillon MJ, Lerner MR, Bronze MS, Brackett DJ. Innate responses to systemic infection by intracellular bacteria trigger recruitment of Ly-6Chigh monocytes to the brain. J Immunol. 2008;181:529-36.

86. D'Mello C, Le T, Swain MG. Cerebral microglia recruit monocytes into the brain in response to tumor necrosis factoralpha signaling during peripheral organ inflammation. J Neurosci. 2009;29:2089-102.

87. Jin R, Yang G, Li G. Inflammatory mechanisms in ischemic stroke: role of inflammatory cells. J Leukoc Biol. 2010;87:779-89.

88. Ousman SS, Kubes P. Immune surveillance in the central nervous system. Nat Neurosci. 2012:15:1096-101.

89. Harden LM, du Plessis I, Roth J, Loram LC, Poole S, Laburn HP. Differences in the relative involvement of peripherally released interleukin (IL)-6, brain IL-1beta and prostanoids in mediating lipopolysaccharide-induced fever and sickness behavior. Psychoneuroendocrinology. 2011;36:608-22.

90. Kozak W, Wrotek S, Kozak A. Pyrogenicity of CpG-DNA in mice: role of interleukin-6, cyclooxygenases, and nuclear factor-kappaB. Am J Physiol Regul Integr Comp Physiol. 2006;290:R871-880.

91. Konsman JP, Parnet P, Dantzer R. Cytokine-induced sickness behaviour: mechanisms and implications. Trends Neurosci. 2002;25:154-9.

92. Frenois F, Moreau M, O'Connor J, Lawson M, Micon C, Lestage J, et al. Lipopolysaccharide induces delayed FosB/DeltaFosB immunostaining within the mouse extended amygdala, hippocampus and hypothalamus, that parallel the expression of depressive-like behavior.

Psychoneuroendocrinology. 2007;32:516-31.

93. Capuron L, Gumnick JF, Musselman DL, Lawson DH, Reemsnyder A, Nemeroff CB, et al. Neurobehavioral effects of interferon-alpha in cancer patients: phenomenology and paroxetine responsiveness of symptom dimensions. Neuropsychopharmacology. 2002;26:643-52.

94. O'Connor JC, Lawson MA, Andre C, Moreau M, Lestage J, Castanon N, et al. Lipopolysaccharide-induced depressive-like behavior is mediated by indoleamine 2,3-dioxygenase activation in mice. Mol Psychiatry. 2009; 14:511-22.

95. Swiergiel AH, Dunn AJ. Effects of interleukin-1 beta and lipopolysaccharide on behavior of mice in the elevated plus-maze and open field tests. Pharmacol Biochem Behav. 2007;86:651-9.

96. Marvel FA, Chen CC, Badr N, Gaykema RP, Goehler LE. Reversible inactivation of the dorsal vagal complex blocks lipopolysaccharide-induced social withdrawal and c-Fos expression in central autonomic nuclei. Brain Behav Immun. 2004;18:123-34

97. Gaykema RP, Goehler LE. Ascending caudal medullary catecholamine pathways drive sickness-induced deficits in exploratory behavior: brain substrates for fatigue? Brain Behav Immun. 2011;25:443-60.

98. Henry CJ, Huang Y, Wynne A, Hanke M, Himler J, Bailey MT, et al. Minocycline attenuates lipopolysaccharide (LPS)-induced neuroinflammation, sickness behavior, and anhedonia. J Neuroinflammation. 2008:5:15.

99. Deacon RM, Brook RC, Meyer D, Haeckel O, Ashcroft FM, Miki T, et al. Behavioral phenotyping of mice lacking the K ATP channel subunit Kir6.2. Physiol Behav. 2006;87:723-33.

100. Deacon RM. Burrowing: a sensitive behavioural assay, tested in five species of laboratory rodents. Behav Brain Res. 2009;200:128-33.

101. Carr DJ, Wuest T, Tomanek L, Silverman RH, Williams BR. The lack of RNA-dependent protein kinase enhances susceptibility of mice to genital herpes simplex virus type 2 infection. Immunology. 2006;118:520-6
102. Stojdl DF, Abraham N, Knowles S, Marius R, Brasey A, Lichty BD, et al. The murine double-stranded RNA-dependent protein kinase PKR is required for resistance to vesicular stomatitis virus. J Virol. 2000;74:9580-5.

103. Campbell BM, Morrison JL, Walker EL, Merchant KM. Differential regulation of behavioral, genomic, and neuroendocrine responses by CRF infusions in rats. Pharmacol Biochem Behav. 2004;77:447-55.

104. Dunn AJ, File SE. Corticotropin-releasing factor has an anxiogenic action in the social interaction test. Horm Behav. 1987;21:193-202.

105. Linthorst AC, Flachskamm C, Hopkins SJ, Hoadley ME, Labeur MS, Holsboer $F$, et al. Long-term intracerebroventricular infusion of corticotropin-releasing hormone alters neuroendocrine, neurochemical, autonomic, behavioral, and cytokine responses to a systemic inflammatory challenge. J Neurosci. 1997:17:4448-60.

106. Kovacs KJ. CRH: the link between hormonal-, metabolic- and behavioral responses to stress. J Chem Neuroanat. 2013;54:25-33.

107. Makino S, Hashimoto K, Gold PW. Multiple feedback mechanisms activating corticotropin-releasing hormone system in the brain during stress. Pharmacol Biochem Behav. 2002;73:147-58.

108. Chen $Y$, Brunson $\mathrm{KL}$, Adelmann G, Bender RA, Frotscher M, Baram TZ. Hippocampal corticotropin releasing hormone: pre- and postsynaptic location and release by stress. Neuroscience. 2004;126:533-40.

109. Kalantaridou S, Makrigiannakis A, Zoumakis E, Chrousos GP. Peripheral corticotropin-releasing hormone is produced in the immune and reproductive systems: actions, potential roles and clinical implications. Front Biosci. 2007;12:572-80.

110. Spiga F, Harrison LR, Wood S, Knight DM, MacSweeney CP, Thomson F, et al. Blockade of the $\mathrm{V}(\mathrm{lb})$ receptor reduces $\mathrm{ACTH}$, but not corticosterone secretion induced by stress without affecting basal hypothalamic-pituitaryadrenal axis activity. J Endocrinol. 2009;200:273-83.

111. Ochedalski T, Rabadan-Diehl C, Aguilera G. Interaction between glucocorticoids and corticotropin releasing hormone $(\mathrm{CRH})$ in the regulation of the pituitary CRH receptor in vivo in the rat. J Neuroendocrinol. 1998;10:363-9.

112. Laryea G, Arnett MG, Muglia LJ. Behavioral studies and genetic alterations in corticotropin-releasing hormone $(\mathrm{CRH})$ neurocircuitry: insights into human psychiatric disorders. Behav Sci (Basel). 2012;2:135-71.

113. Refojo D, Schweizer M, Kuehne C, Ehrenberg S, Thoeringer C, Vogl AM, et al. Glutamatergic and dopaminergic neurons mediate anxiogenic and anxiolytic effects of CRHR1. Science. 2011;333:1903-7.

114. Blank T, Nijholt I, Eckart K, Spiess J. Priming of long-term potentiation in mouse hippocampus by corticotropin-releasing factor and acute stress: implications for hippocampus-dependent learning. J Neurosci. 2002;22:3788-94.

115. Engblom D, Saha S, Engstrom L, Westman M, Audoly LP, Jakobsson PJ, et al. Microsomal prostaglandin E synthase- 1 is the central switch during immune-induced pyresis. Nat Neurosci. 2003;6:1137-8.

116. Pecchi E, Dallaporta M, Thirion S, Salvat C, Berenbaum F, Jean A, et al. Involvement of central microsomal prostaglandin E synthase-1 in IL-1beta-induced anorexia. Physiol Genomics. 2006;25:485-92.

117. Schneiders J, Fuchs F, Damm J, Herden C, Gerstberger R, Soares DM, et al. The transcription factor nuclear factor interleukin 6 mediates pro- and anti-inflammatory responses during LPS-induced systemic inflammation in mice. Brain Behav Immun. 2015;48:147-64

118. Harada S, Imaki T, Chikada N, Naruse M, Demura H. Distinct distribution and time-course changes in neuronal nitric oxide synthase and inducible NOS in the paraventricular nucleus following lipopolysaccharide injection. Brain Res. 1999:821:322-32

119. Mouton-Liger F, Paquet C, Dumurgier J, Bouras C, Pradier L, Gray F, et al. Oxidative stress increases BACE1 protein levels through activation of the PKR-elF2alpha pathway. Biochim Biophys Acta. 1822;2012:885-96.

120. Mouton-Liger F, Rebillat AS, Gourmaud S, Paquet C, Leguen A, Dumurgier J, et al. PKR downregulation prevents neurodegeneration and beta-amyloid production in a thiamine-deficient model. Cell Death Dis. 2015;6, e1594.

121. Bose A, Mouton-Liger F, Paquet C, Mazot P, Vigny M, Gray F, et al. Modulation of tau phosphorylation by the kinase PKR: implications in Alzheimer's disease. Brain Pathol. 2011:21:189-200.

122. Chang RC, Suen KC, Ma CH, Elyaman W, Ng HK, Hugon J. Involvement of double-stranded RNA-dependent protein kinase and phosphorylation of eukaryotic initiation factor-2alpha in neuronal degeneration. J Neurochem. 2002;83:1215-25.

123. Zhu PJ, Huang W, Kalikulov D, Yoo JW, Placzek AN, Stoica L, et al. Suppression of PKR promotes network excitability and enhanced cognition by interferon-gamma-mediated disinhibition. Cell. 2011;147:1384-96. 